\title{
Assessing Forest Sustainability: Evidence from Spanish Provinces
}

\author{
Javier Martínez-Vega, Samir Mili, Pilar Echavarría \\ Institute of Economics, Geography and Demography, Spanish National Research Council, Albasanz 26-28, 28037 Madrid, Spain.
}

Keywords: Sustainability, indicators, forest, Spanish provinces.

\begin{abstract}
This article aims to assess the sustainability of forestry in Spain at provincial scale from two points of view: first, a multidimensional perspective considering the three classical dimensions of sustainability environmental, economic and social - and, second, an integrative approach estimating a global index for forest sustainability. While the construction of such a global index is methodologically difficult and arguable, it could be very useful to land planners when drawing up and reviewing forestry and environmental policies. The global index of forest sustainability suggested in this study is calculated for the fifty Spanish provinces, based on a selection of twenty indicators. The majority of them (thirteen) relate to environmental dimension, four to economic dimension and three to social dimension. Numerous statistics and cartographic sources are used. A methodology is proposed based on grouping selected indicators according to three intermediate composite indicators and, subsequently, a global super-index. Cluster analysis establishes four different types of provinces according to their forest sustainability. According to the global sustainability index, part of the forests of the Mediterranean coast, those located near large inland cities and in southern Galicia appear to be less sustainable as a consequence of land artificialisation processes and forest fires. Conversely, Atlantic and Pyrenees forests, and those of the northern Plateau are more sustainable due to their relative success in keeping forest traditional uses and containing emerging threats.
\end{abstract}

\section{Introduction}

There is a widespread agreement in the specialised literature that despite their socio-economic and environmental importance, worldwide forests are under persistent and in many cases growing threats such as deforestation (FRA, 2010), forest fires (Chuvieco et al., 2013), fragmentation (Dantas de Paula et al., 2015) and the spread of invasive alien species (Lei et al., 2014). Furthermore, although the pace of deforestation has slowed it is still alarming. The decade 2000-2010 has seen an annual loss of 5.2 million forest hectares worldwide. Net deforestation rate was $0.14 \%$ per annum between 2005 and 2010 (FRA, 2010). Moreover, although there are many programs for reforestation of agricultural land, young plantations are not comparable to primary forests, both in ecological and biodiversity terms (FRA, 2010; Fonseca et al., 2011).

Therefore, there is globally a growing concern about forest sustainability (FAO, 2014) and Spain is no exception. It is established that well-managed forests contribute positively to sustainable development and promote the mitigation of climate change effects and food security. In the framework of the European Union (EU), taking into account the trans-boundary nature threats and the absence of a common forestry policy, common action is required in line with the new EU Forest Strategy (European Commission, 2013). However, despite the apparent interest in ensuring forest sustainability globally as well as in Europe and Spain, there are few research studies that quantify sustainability considering territorial demarcations related to managerial and policy decision-making. In Spain, to our knowledge this is the first study assessing the sustainability of forest systems at provincial scale.

Against this backdrop, the main objective of this article is to assess sustainability of forestry in Spain at province level using a panel of selected indicators. It proposes an operational methodology for calculating a global sustainability index at an intermediate level of analysis from the administrative and territorial point of views (province). In addition, it classifies provinces by their characteristics and their forest sustainability. It is intended that the suggested methodology 
(indicators, measuring scales, integration procedure) is applied in a standardised and regular fashion in the future to understand the spatial and temporal trends of forest sustainability in each province and each cluster of provinces.

The starting premises are that (1) Spain has an extensive and valuable forest estate which supports protected habitats and species at national, European and global level, (2) special effort should be made to preserve this heritage because it is very vulnerable and is subject to various environmental hazards (forest fires, soil erosion, climate change, land use change, among others), and (3) given the significant differences in the state of forestry in distinct provinces, it is convenient to study whether exists a geographic gradient that explains these differences.

\section{Measuring sustainability: literature review}

Since the concept of sustainable development was first used (WCED, 1987), many studies on land sustainability have been published from different perspectives but always conceiving it as a desirable aim for balanced land development (Böhringer and Jochem, 2007; Blanchet, 2012; Mori and Christodoulou, 2012; Gerdessen and Pascucci, 2013, amongst others). There are various systems of sustainability indicators that help to measure, to dynamically monitor sustainability and to make comparisons between different territories (OECD, 1998; Eurostat, 1999). Many of the studies use a long list of indicators - from more than 30 (ITTO, 2003) to over 100 (MCPFE, 1998). Some indicators are repeated, especially those included in standard international systems. Others differ from one study to another depending on their objective (Grainger, 2012). There are also differences in the way they are expressed mathematically or calculated (Gerdessen and Pascucci, 2013), or in the sources of information they use. There is no universally-accepted list of indicators (Mori and Christodoulou, 2012), although general criteria have been given for selecting them depending on the way they relate to the concepts, definitions and dimensions of sustainability, as well as the opinion of experts and the availability of information on the corresponding unit of analysis (Rodrigues et al., 2010; Gerdessen and Pascucci, 2013).

Moreover, a wide variety of approaches has been adopted (Grainger, 2012). Some use quantitative (Rodrigues et al., 2010; Ojea et al., 2012) or qualitative indicators (Mather, 2001; FAO, 2002), and some use static or dynamic indicators (Van Dijk and Zhang, 2005; Pan and Kao, 2009; Rodrigues et al., 2010) based on time series that make it possible to determine sustainability trends in specific territories (Hara et al., 2009). There are also topdown approaches led by managers as opposed to bottom-up systems in which civil society participation is essential. Other more recent approaches are based on methods known as KAF (Knowledge-Action-Framework, Grainger, 2012) or use a mini score card (Blanchet, 2012) that does not combine all the indices.

From the methodological point of view, previous studies have used various methods and models for analysing sustainability: principal component analysis (Morse and Fraser, 2005; Bastianoni et al., 2008), cluster analysis (Bastianoni et al., 2008), colorimetric maps and mosaics to give visual information to users (Martínez-Vega et al., 2009), economic models based on the principle of opportunity costs (Ang and Van Passel, 2010), optimisation algorithms based on eco-efficiency models, multi-criteria and multi-attribute decisionmaking models to simulate future scenarios (Gerdessen and Pascucci, 2013), and models based on linear programming (Van Calker et al., 2008). There are increasing numbers of studies in which the analysis of sustainability and its indicators is linked to participation by the local population (Fraser et al., 2006) and consultation with experts (Van Dijk and Zhang, 2005). Other authors mention the requirements that have to be taken into account for designing a composite (Böhringer and Jochem, 2007) or ideal sustainability index (Mori and Christodoulou, 2012).

There is no consensus on the number of dimensions that explain sustainability. Many studies identify two main dimensions: environmental and economic (Van Passel et al., 2007), economic and social (Van Calker et al., 2007) and, more broadly, environmental and socio-economic (Dantsis et al., 2010). The most classic studies, as well as other more recent ones, identify three main dimensions environmental, economic and social (Nijkamp, 1990; Gerdessen and Pascucci, 2013). In some cases, a fourth institutional dimension is added (Van Dijk and Zhang, 2005). Others claim that sustainability has five dimensions - ecological, environmental, economic, socio-cultural and managerial (Rodrigues et al., 2010).

Regarding sustainability scales, many studies have examined sustainability on different territorial scales: national (Grainger, 2012), regional (Gerdessen and Pascucci, 2013), provincial (Hara et al., 2009) and local (Rodrigues et al., 2010; Ojea et al., 2012). Obviously, each scale requires the use of different basic units of territorial information, from countries to farms or tree stands. 


\section{Data and methods}

The study area considered in this contribution is Spain which has a total population of 46,464,053 inhabitants distributed over $505,968 \mathrm{~km}^{2}$. Population density is 92 inhabitants per $\mathrm{km}^{2}$. Administratively it is divided into 17 regions and 50 provinces (Figure 1). The forest area $^{1}$ in Spain is the fourth largest in Europe, accounting for a total of almost 26 million hectares in 2006. 35\% of that total (9.1 million hectares) has tree coverage. Spain has great biogeographical diversity. It is located in one of the 25 world hotspots, which are critical for biodiversity conservation (Myers et al., 2000).

Among its forestry systems are forests of beech, fir, pine, oak and laurel. Its territory includes four biogeographic regions: Atlantic, Alpine, Mediterranean and Macaronesian (Rivas-Martínez et al., 1990). Forest ecosystems located in the latter region are rare and unique in the EU. The most diverse forest ecosystems are the forests of the Cantabrian Mountains and Pyrenees, followed by those in the Iberian mountain range, the Central System, Sierra Morena and the pastures of Extremadura and Salamanca (Martínez-Vega et al., 2012).

As a result of the rural exodus and other socioeconomic changes that have taken place since the 1960s, scrub has invaded abandoned farming land and former animal pastures. There has also been a process of increasing biomass in the natural parts of the peninsula's main mountain areas and the western peneplains (Stellmes et al., 2013). This increase in biomass provides plenty of fuel for fires, and its geographical expansion increases the propagation of forest fires (Chuvieco et al., 2012), as well as the socio-economic vulnerability (Román et al., 2013) and ecological vulnerability (Duguy et al., 2012) of forest ecosystems. In addition, important changes are expected in the spatial distribution of forests in Spain as a result of the on-going abandonment of farming land and of pasturelands, the invasion of scrub and the densification of forests (Stellmes et al., 2013).

Spanish mountains are constantly threatened. The main threats are the consequence of: (a) the geographical location of Spain in a vulnerable transition area between the Mediterranean temperate climate, with recurring temperature and precipitation imbalances (de Luis et al., 2010), and arid sub-desert climates, (b) natural risks (lightning, pests), (c) the risk of forest fires (Chuvieco et al., 2012) and the high vulnerability of land to fire (Chuvieco et al., 2013; Román et al., 2013), (d) the long time for natural recovery of vegetation after severe forest fires (Rodrigues et al., 2014), (e) changes in land use
(Lasanta and Vicente-Serrano, 2012; Stellmes et al., 2013; Martínez-Fernández et al., 2015), (f) the scenarios to be expected from climate change (García-Ruiz et al., 2011) and changes in land use and their relation to the risk of forest fires and the capture of $\mathrm{CO}_{2}$ by forests (Colombo et al., 2012; Ruiz-Benito et al., 2014), (g) pressure from urban development $(\mathrm{h})$ recreational pressure (i) the marked and constant de-population of large rural area of inland Spain.

\subsection{Indicator selection}

Taking the specialised literature and international and European sustainability indicator systems (Costanza et al., 1997; Spangenberg, 1998; European Commission, 2006; Pintus and Giraud, 2009; FOREST EUROPE-UNECE-FAO, 2011; Rametsteiner et al., 2011; Pülzl et al., 2012), the different forest sustainability indicators were reviewed and 28 were pre-selected. Special attention has been paid in this stage to reduce as far as possible arbitrariness in the selection. In addition, numerous experts in the field have been consulted (stakeholders and scientists from different disciplines) ${ }^{2}$. It should be pointed out that however theoretically relevant are certain indicators they cannot be used in a practical case study if data are not available at the required spatial and temporal resolution. They also are hardly comparable if there is no agreement on the desirable trend or target value (TV) to be reached.

Subsequently, 20 indicators that summarise 96 variables were selected to measure forest sustainability in Spain (Appendix 1). Each of them was classified and related to the dimensions, sectors and factors of forest sustainability. Most of the indicators $(65 \%)$ are linked to the environmental dimension and provide information on the pressure $(\mathrm{P})$, status $(\mathrm{S})$ or response $(\mathrm{R})$ of different sectors (forests, landscape, biodiversity and climate change) and factors behind it (forest resources, damage, conservation measures, landscape diversity, protected areas, air quality and erosion). Some indicators $(20 \%)$ provide very relevant information on the economic function of Spanish forest areas, not only the productive functions but also recreational functions and environmental services. Finally, a few social indicators $(15 \%)$ were selected to provide information on aspects of rural development.

\subsection{Data collection}

A wide range of sources of information were used. Wherever possible, priority was placed on cartographic sources for calculating the indicators 


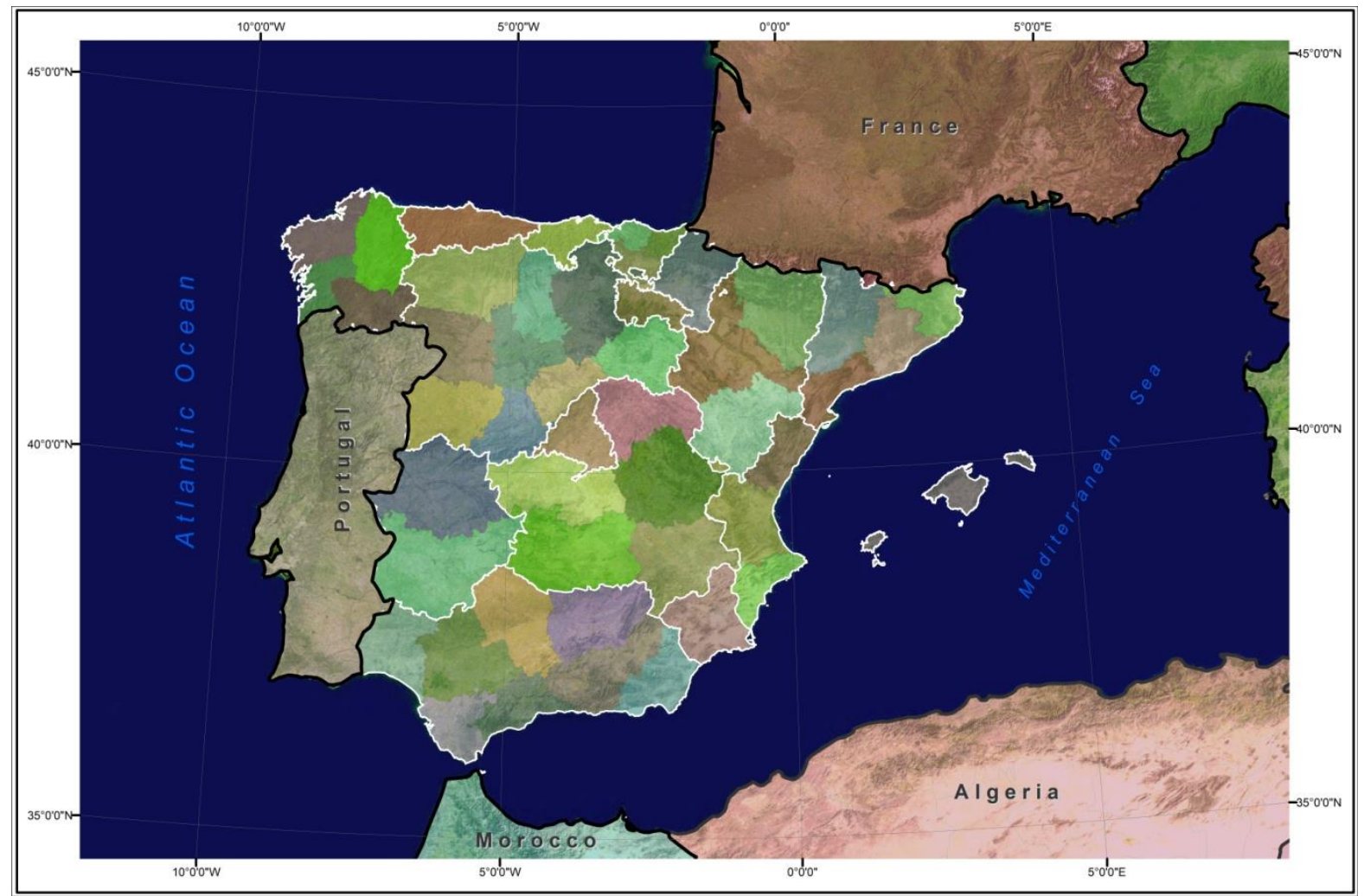

Fig. 1. Study area.

because these are considered more reliable and precise. The cartographic series used included CORINE-Land Cover for the years 2000 and 2006, the Spanish forest map and inventory, the map of erosion, the National Atlas of Spain, data bases on forest fires (2006 to 2010) from the Ministry of the Environment, corporate GIS data such as those from EUROPARC-España

(http://opengis.uab.es/wms/europarc/, last accessed December $16^{\text {th }} 2015$ ), and cartographic data from research projects related to the topics analysed (FIREGLOBE

http://www.geogra.uah.es/fireglobe/index.php/ctmenu-item-35, last accessed December $16^{\text {th }} 2015$-, FUME - http://fumeproject.uclm.es/- last accessed December $16^{\text {th }}$ 2015). In addition, statistics from various censuses (population, farming) and company directories were used.

\subsection{Data analysis and statistical methods}

Statistical and spatial analyses were performed by means of SPSS v22 and ARC-GIS v10, respectively. The original data were transformed (TfV, transformed values) in line with the method proposed for calculating each indicator, and are expressed in the corresponding unit of measurement (Appendix 1). In some cases, the raw data were related to surface units to make them comparable and to establish a ranking of provinces. The FOR_CS indicator relates the total volume of $\mathrm{CO}_{2}$ captured by forests in each province with its forest surface area in order to express the indicator in tonnes/ha. Similarly, the FOR_FA_tree_cap indicator expresses the tree-covered surface in each province per inhabitant

In the four indicators that amount to a threat for environmental (FOR_BAI, CGC_GEI_TOT, CGC_ERO) and social (AGR_SF) sustainability, the original values for the indicators were reversed, deducting them from 100 (better sustainability), in order to be able to add them to the other indicators that measure the environmental and social sustainability of each province. This operation was not necessary for calculating economic sustainability because the desirable trends in all indicators move in an upward direction. Following the recommendations of Morse and Fraser (2005) and in order to standardise the data and achieve normalised values (NV), the TfV were divided by a target value (TV) for each indicator, this being the desirable 
minimum value in the context of sustainability (Maes et al., 2011), so that:

$$
\begin{gathered}
N V_{i}=\frac{T f V_{i}}{T V} \\
\mathrm{i}=1 \ldots . .50 \text { provinces }
\end{gathered}
$$

Appendices 2 to 4 give detailed information on how the target values for each indicator were obtained. In some cases, the forecasts and targets set in territorial strategies or sector plans (Spanish Forestry Plan, 2002-2032) were taken into account. Regarding environmental indicators for which no clear references were found in the scientific literature, the legislation or sector plans, the maximum value possible was set as the ideal value (100), which was considered feasible though difficult to achieve. However, for the economic indicators for which there are no clear, widely accepted references, the distribution of frequency of values for each province was taken into account, and the target value was set at percentile 85 . For the HA_GDP indicator, designed as an index based on 100 , the target value is 100 . The aim pursued is at least to maintain the income level of the population. Finally, in the absence of binding legal or bibliographical references, the target values of the social indicators were set at the mean (AGR_NFE) or at percentile 80 (AGR_SF, AGR_ASE). The target values were altered considering, in each case, that they represent minimum values to be achieved, depending on the distribution of the indicators' current values.

In some cases (indicators FOR_AR, LAND_SDI, BIO_TPA and BIO_RN2000), data is missing for some insular provinces of Spain. When integrating the environmental indicators, the intermediate index for forestry environmental sustainability (FOR_ESI) did not consider these missing values. The reflections made in previous studies (Morse and Fraser, 2005) that criticise the estimation of "no data" using logistic regression to calculate the environmental sustainability index (ESI) were taken into account because they lead to bias in calculations.

When the indicators were integrated, a decision on whether or not to apply weights to the different indicators and to the intermediate indices was necessary. Some are considered by international systems of sustainability indicators to have priority. As shown in the fourth column of Appendix 1, 14 indicators take priority while six are considered complementary. Morse and Fraser (2005) explain the assignation of different weights to each of the five components of the ESI depending on the number of indicators each of them contains.
However, Böhringer and Jochem (2007) indicate that the processes of assigning weights are very arbitrary. In the end and in view of this controversy, different weights were not assigned to the indicators or to the intermediate indices, in spite of their unequal relevance and priority. It was preferred to make no distinction and to consider all the indicators and intermediate indices equally.

In the next stage, the normalised indicators were included in intermediate indices, relating each of them with one dimension of forest sustainability. Our purpose was to obtain one index for environmental sustainability (FOR_ESI), another for economic sustainability (FOR_ECOSI) and another for social sustainability (FOR_SSI), for each of the Spanish provinces. The average value of all the indicators for each dimension (environmental, economic and social) was calculated using the following equations:

FOR.ESIi $=($ MEAN $($ FOR_FAi,CGC.EROi $)-1) \times 100$ FOR.ECOSIi $=($ MEAN $($ FOR_ESPFi,HA_GDPi $)-1) \times 100$ FOR_SSIi $=\left(\right.$ MEAN $\left.\left(A G R \_N F E i, A G R \_A S E i ~\right)-1\right) \times 100$

$$
\mathrm{i}=10 \ldots 50 \text { province }
$$

By way of example, in FOR_ESI $i_{i}$ the values of the 13 environmental indicators listed in Appendix 1 are considered, from the ratio of forest area to total surface area (FOR_FA) to the percentage of area affected by high rates of erosion related to the erodible surface area (CGC_ERO), in each of the Spanish provinces, i.e. from province 1 (Coruña) to province 50 (SC Tenerife).

The values obtained for the environmental, economic and social indices for the forest sector in each province were transformed into $\mathrm{Z}$ units in order to harmonise their measurements. This was done using the following equation:

$$
Z_{i}=\frac{X_{i}-\bar{X}}{\hat{\sigma}_{X}}
$$

Where $X_{i}$ are original values, $\bar{X}$ the mean of the series and $\hat{\sigma}_{X}$ the standard deviation of the series. $Z_{i}$ indicate how many units each province is away from the general mean.

In the next stage, the global forest sustainability index (FOR_GSI) was calculated as a simple average of the above sector indices relating to each of the dimensions of sustainability.

And an adjusted average value was calculated for this global forest sustainability index in $\mathrm{Z}$ units. 


$$
\begin{gathered}
F O R_{-} G S I_{i}=\frac{F O R_{-} E S I_{i}+F O R_{-} E C O S I_{i}+F O R_{-} S S I_{i}}{3} \\
Z_{-} F O R_{-} G S I_{i}=\frac{Z_{-} F O R_{-} E S I_{i}+Z_{-} F O R_{-} E C O S I_{i}+Z_{-} F O R_{-} S S I_{i}}{\sqrt{3}}
\end{gathered}
$$

In addition, a matrix of correlations was calculated in order to carry out a relational analysis between the indicators comprising each index and the three sector indices for sustainability that make up FOR_GSI.

Subsequently, a k-means cluster analysis on the standardised variables was performed in order to classify the Spanish provinces studied in homogeneous groups, in line with their environmental, economic and social characteristics.

In the last stage, the location of the cases studied (50 provinces) was shown graphically to compare their relative positions regarding sustainability, both sectorial and global. Some studies (Nijkamp, 1990) indicate conceptually the advisability of representing sustainability on a triangle, as this figure suits its three dimensions, or on a prism, if the fourth institutional dimension is considered (Spangenberg, 1998). Triangular diagrams are used to represent a constant amount divided by three variable elements. Each point on an equilateral triangle is determined by three coordinates. However, a triangular diagram has several drawbacks, including the difficulty of measuring the values of the points, because the axes are not orthogonal. In addition, in our case, from a methodological point of view, a triangular diagram is neither to be recommended nor feasible because the values of the social, economic and environmental dimensions do not complement each other (Martínez-Vega et al., 2009), which is an essential condition for triangular diagrams.

In order to avoid these drawbacks, a cube was used as an alternative method for representing the global sustainability of the provinces studied. The values of the Z_FOR_ECOSI, Z_FOR_ESI and Z_FOR_SSI indices are represented, respectively on the $\mathrm{x}, \mathrm{y}, \mathrm{z}$ axes of the cube, duly scaled. This type of graphic representation can be easily interpreted by end users (managers, other stakeholders and the general public). The higher the centroid of a province on the cube, the further to the right and the front, the greater is its global sustainability. This figure also shows the four clusters of provinces, differentiated by colour.

In addition, the spatial distribution of the four groups of provinces, differentiated by cluster analysis according to their forest sustainability, was represented cartographically using a choropleth map.
This is a simple method that is easy to interpret by end users and decision-makers. Other cartographic techniques, such as krigging (Martínez-Vega et al., 2009), were avoided because the province data are very heterogeneous and the possibility of continuing with such units is unclear.

Moreover, as mentioned before, in the process of data integration into a synthetic index, no weights have been assigned to indicators and dimensions (Böhringer and Jochem, 2007). To assess the influence of this decision on the results, we have compared the values of global sustainability index with those obtained if different weights are applied to indicators (greater weight to the priority indicators) and dimensions (proportional weight according to the number of indicators of each dimension), as suggested by Morse and Fraser (2005)

\section{Results}

As stated above, Spain has a valuable forest heritage. $52.62 \%$ of Spain's surface area is covered by forest. This area has captured about 417.5 million tonnes of $\mathrm{CO}_{2}$, helping to improve air quality. The tree-covered surface area also produces $60 \mathrm{~m}^{3} / \mathrm{ha}$ of tree biomass. Economically, Spanish woodland has a strategic role to play. It provides annual averages of $385,000,163,000$ and $412,000 €$ per $\mathrm{km}^{2}$ through its productive, recreational and environmental services respectively.

Appendices 2 to 4 give additional details on the results of all the selected indicators for the 50 Spanish provinces. Table 1 shows in summarised form the extreme values (the worst and the best) for each indicator together with the target value, in line with territorial policies and strategies, both national and European, and sector policies. As can be seen some of the targets have already been reached by Spain as a whole and by many Spanish provinces. For example, the target value for growth of GDP per capita (HA_GDP indicator) has been exceeded by the country as a whole and all provinces. For other indicators (e.g. FOR_CS indicator), the target value is close to be achieved by the whole Spain. The Spanish Forest Plan (2002-2032) sets a storage target for Spanish forests of 477.5 million tonnes of carbon by 2032. This amount is justified by the expected reforestation of 3.8 million hectares and the improvement of forest management. It represents an average carbon storage of 16.02 tonnes per hectare of forest area. Currently, more than half of the Spanish provinces far exceed this target value. In some cases, such targets are not met because of the size of the threats. The above-mentioned forest plan provides for the burning of a maximum of $0.2 \%$ of the national forest area by 2032 . According to the 
Table 1

Summary of values by forest sustainability indicators and dimensions

\begin{tabular}{|c|c|c|c|c|c|}
\hline Dimension & Code & Indicator & $\begin{array}{c}\text { Worst Value } \\
\text { (WT) }\end{array}$ & $\begin{array}{c}\text { Best Value } \\
\text { (BV) }\end{array}$ & $\begin{array}{c}\text { Target Value } \\
\text { (TV) }\end{array}$ \\
\hline \multirow{13}{*}{ 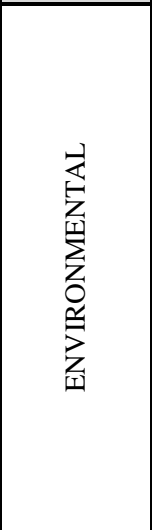 } & FOR_FA & Share of forest area & 16,54 & 80,63 & 58,87 \\
\hline & FOR_CS & Carbon Stock & 3,56 & 26,77 & 16,02 \\
\hline & FOR_AR & Afforestation rate & $-2,60$ & 3,52 & 5,40 \\
\hline & FOR_FA_tree & Rate of stocked forest area & 5,94 & 74,07 & 65,00 \\
\hline & FOR_FA_tree_ & Rate of stocked forest area per capita & 0,01 & 2,62 & 0,45 \\
\hline & \begin{tabular}{|l} 
FOR_BAI \\
\end{tabular} & Rate of burned area & 96,84 & 99,64 & 99,80 \\
\hline & FOR_P ${ }_{1} \mathrm{~F}$ & Protected Forests & 7,31 & 84,48 & 100,00 \\
\hline & FOR_P ${ }_{2} \mathrm{~F}$ & Protective Forests & 0,34 & 80,16 & 100,00 \\
\hline & LAND_SDI & Simpson Diversity Index & 18,47 & 45,58 & 100,00 \\
\hline & BIO_TPA & Percentage of Terrestrial Protected Areas & 10,67 & 87,21 & 100,00 \\
\hline & BIO_RN2000 & Ratio of forest areas under Natura 2000 network & 19,51 & 86,01 & 100,00 \\
\hline & CGC_GEI_TOT & Total greenhouse gas emissions & 0,01 & 99,96 & 100,00 \\
\hline & CGC_ERO & Erosion & 37,60 & 96,11 & 100,00 \\
\hline \multirow{4}{*}{ 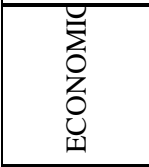 } & FOR_ESPF & Productive function & 18,53 & $2.437,55$ & 734,86 \\
\hline & FOR_ESRF & Recreational function & 35,15 & 546,26 & 196,37 \\
\hline & FOR_ESES & Environmental services & 91,60 & 915,10 & 614,04 \\
\hline & HA_GDP & Growth of GDP per capita & 132,66 & 177,42 & 100,00 \\
\hline \multirow{3}{*}{ 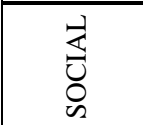 } & AGR_NFE & Non-farming enterprises & 35,66 & 98,41 & 68,00 \\
\hline & AGR_SF & Small farms & 4,06 & 81,06 & 55,18 \\
\hline & AGR_ASE & Agricultural hired employment & 4,15 & 75,60 & 41,50 \\
\hline
\end{tabular}

data series for 2006-2010, 31 provinces met this target, many of them along the Mediterranean coast. During the same period, forest fires affected an annual average of $0.36 \%$ of the national forest area. The worst situation is seen in certain provinces in Galicia. $3.16 \%$ of the forest area of Pontevedra has been burnt annually.

Table 2 summarises the values reached in each province in the environmental, economic, social and global sustainability indices as well as in the cluster to which each province belongs. Today, $2 \%$ of Spanish provinces are above the desirable minimum value for environmental sustainability. $30 \%$ of provinces exceed desirable minimum value for economic sustainability, $10 \%$ for social sustainability and $2 \%$ for global sustainability.

Map A (Appendix 5) shows the values for the environmental sustainability index of forestry (FOR_ESI) by province. Provinces in the south-east of Spain, the most arid part, are the ones with the worst figures, together with the Las Palmas de Gran Canaria, Coruña and Pontevedra, because of tourism and urban development pressure, the competition from intensive fruit and vegetable farming and forest fires. Such activities have transformed and consumed great expanses of natural land and exert pressure on woodlands, endangering their conservation. On the other hand, the extensive and well-kept Mediterranean woodlands in the provinces of Iberian Mountains, the Pyrenees and the northern plateau are the most environmentally sustainable. They are used for traditional forestry purposes

Map B (Appendix 5) represents the economic sustainability index for forestry (FOR_ECOSI) by province. The high values for the production function of the Cantabrian and Atlantic woodlands in northern Spain explain the good values for this index in the northern provinces. The influence of climate may explain the difference in economic performance of the mountains of Orense located in a transition zone between the Mediterranean and Atlantic biogeographic regions, and of those of Pontevedra. Zamora and Salamanca owe their good position in the ranking to balance among all the functions of their woodlands. A paradigmatic example is the province of Las Palmas in the Canaries that bases its good classification on the high value obtained by the recreational function of its woodlands. Map C (Appendix 5) shows the social sustainability index for forestry (FOR_SSI) on a provincial scale. The number of jobs provided by companies in the primary sector and economic diversification explain the good results of the better classified provinces.

Figure 2 shows a choropleth map expressing the global sustainability index for Spanish forestry (Z_FOR_GSI) by province. Visually, there is a marked difference between provinces along the Mediterranean together with the two southern 
Table 2

Values of sectorial and global sustainability indices, descriptive statics and grouping of provinces.

\begin{tabular}{|c|c|c|c|c|c|c|}
\hline CLUSTER & NUTS 3 & PROVINCE NAME & Z_FOR_ESI & Z_FOR_ECOSI & Z_FOR_SSI & Z_FOR_GSI \\
\hline \multirow[t]{15}{*}{1} & ES113 & Ourense &,- 5711 &,- 1418 & $-1,6884$ & $-0,8004$ \\
\hline & ES300 & Madrid &,- 7417 &,- 3883 &, 1846 &,- 3151 \\
\hline & ES411 & Ávila & ,4540 &,- 3558 &,- 3153 &,- 0724 \\
\hline & ES432 & Cáceres &,- 2403 &,- 5808 &,- 1247 &,- 3152 \\
\hline & ES514 & Tarragona &,- 5964 & -6910 &,- 8918 &,- 7264 \\
\hline & ES521 & Alicante & $-1,6567$ &,- 8034 &,- 8159 & $-1,0920$ \\
\hline & ES522 & Castellón &,- 4043 &,- 8378 &,- 9329 &,- 7250 \\
\hline & ES523 & Valencia &,- 5350 &,- 4209 &,- 7278 &,- 5612 \\
\hline & ES530 & Baleares &,- 4600 &,- 5711 & -6819 &,- 5710 \\
\hline & ES611 & Almería & $-1,4988$ & $-1,0754$ &,- 1825 &,- 9189 \\
\hline & ES614 & Granada &,- 5737 &,- 4391 &,- 4221 &,- 4783 \\
\hline & ES616 & Jaén & ,2979 &,- 3287 &,- 1128 &,- 0479 \\
\hline & ES617 & Málaga &,- 8759 &,- 4322 &,- 4241 &,- 5774 \\
\hline & ES701 & Palmas, Las & $-1,2602$ &, 8046 &,- 0206 &,- 1587 \\
\hline & ES702 & SC Tenerife &,- 1548 &, 5121 &,- 5460 &,- 0629 \\
\hline \multirow[t]{13}{*}{2} & ES211 & Álava & ,9020 & 6089 &, 4442 & ,6517 \\
\hline & ES220 & Navarra & ,4809 & ,4121 & ,4053 & ,4328 \\
\hline & ES230 & Rioja, La & ,9446 &,- 0101 &,- 1319 & ,2676 \\
\hline & ES241 & Huesca & 1,9667 &,- 3236 &, 5601 & ,7344 \\
\hline & ES242 & Teruel & 2,3079 &,- 6475 &,- 2206 & , 4799 \\
\hline & ES412 & Burgos & ,9272 &, 1241 & ,9586 & ,6700 \\
\hline & ES413 & León & 1,3521 & , 1832 &,- 4062 &, 3763 \\
\hline & ES416 & Segovia & 8506 & $-1,1407$ & 1,2454 & 0,3184 \\
\hline & ES417 & Soria & 2,9669 &, 5606 & 1,2264 & 1,5846 \\
\hline & ES423 & Cuenca & 1,7651 &,- 3589 & ,0121 & , 4728 \\
\hline & ES424 & Guadalajara & 1,3282 &,- 4307 & 1,1937 & 0,6970 \\
\hline & ES512 & Girona &, 7174 & ,4613 &, 7127 & ,6305 \\
\hline & ES513 & Lleida & ,7095 &,- 1488 & ,7375 & ,4327 \\
\hline \multirow[t]{13}{*}{3} & ES243 & Zaragoza & -6554 & -6447 &, 5735 &,- 2422 \\
\hline & ES414 & Palencia &, 5233 & $-1,1733$ & 1,3341 & 0,2281 \\
\hline & ES418 & Valladolid & -6119 & $-1,2946$ & 1,5477 &,- 1196 \\
\hline & ES421 & Albacete &,- 2093 &,- 7136 & ,3921 &,- 1769 \\
\hline & ES422 & Ciudad Real & $-1,0781$ &,- 8871 & ,3496 &,- 5385 \\
\hline & ES425 & Toledo &,- 7446 &,- 7835 & ,3463 &,- 3939 \\
\hline & ES431 & Badajoz &,- 7711 &,- 6237 & ,6059 &,- 2630 \\
\hline & ES511 & Barcelona &,- 3036 & ,0046 &, 3742 & ,0251 \\
\hline & ES612 & Cádiz & -6669 &,- 1372 & 8846 & ,0268 \\
\hline & ES613 & Córdoba &,- 7249 &,- 5852 & 1,0577 & $-0,0842$ \\
\hline & ES615 & Huelva & ,2776 & -6029 & 1,9611 & 0,5453 \\
\hline & ES618 & Sevilla & $-1,0926$ &,- 5066 & 1,6658 & 0,0222 \\
\hline & ES620 & Murcia & $-1,1374$ &,- 5383 & ,9694 &,- 2354 \\
\hline \multirow[t]{9}{*}{4} & ES111 & Coruña, A &,- 9366 & 1,4254 & $-1,7491$ &,- 4201 \\
\hline & ES112 & Lugo & ,6324 & 1,0181 & $-1,3482$ & 0,1008 \\
\hline & ES114 & Pontevedra &,- 9076 & ,7329 & $-1,9668$ &,- 7138 \\
\hline & ES120 & Asturias & 0270 & ,6536 & $-1,3345$ &,- 2180 \\
\hline & ES130 & Cantabria & , 1030 & 1,0750 &,- 6790 & 0,1663 \\
\hline & $\mathrm{ES} 212$ & Guipúzcoa & , 1508 & 3,2055 & $-2,0055$ & 0,4502 \\
\hline & ES213 & Vizcaya &,- 6162 & 3,3975 & $-2,1039$ & 0,2258 \\
\hline & ES415 & Salamanca &,- 1299 & 1,3654 & ,4360 & 0,5572 \\
\hline & ES419 & Zamora & ,4696 & 2,0727 &,- 3464 & 0,7320 \\
\hline \multicolumn{3}{|c|}{ Minimum value } & $-1,6567$ & $-1,2946$ & $-2,1039$ & $-1,0920$ \\
\hline \multicolumn{3}{|c|}{ Maximum value } & 2,9669 & 3,3975 & 1,9611 & 1,5846 \\
\hline \multicolumn{3}{|c|}{ Average (1) } & 0,0000 & 0,0000 & 0,0000 & 0,0000 \\
\hline \multicolumn{3}{|c|}{ Standard Deviation (1) } & 1,0000 & 1,0000 & 1,0000 & 1,0000 \\
\hline \multicolumn{3}{|c|}{ Number of cases } & 50 & 50 & 50 & 50 \\
\hline
\end{tabular}

(1): $\mathrm{Z}$ units and indices are designed in such a way that users know if a province is above or below average and by how much. With this design, obviously, the average should be 0 (values for good provinces are compensated for by those for bad provinces) and the standard deviation should be 1 . 


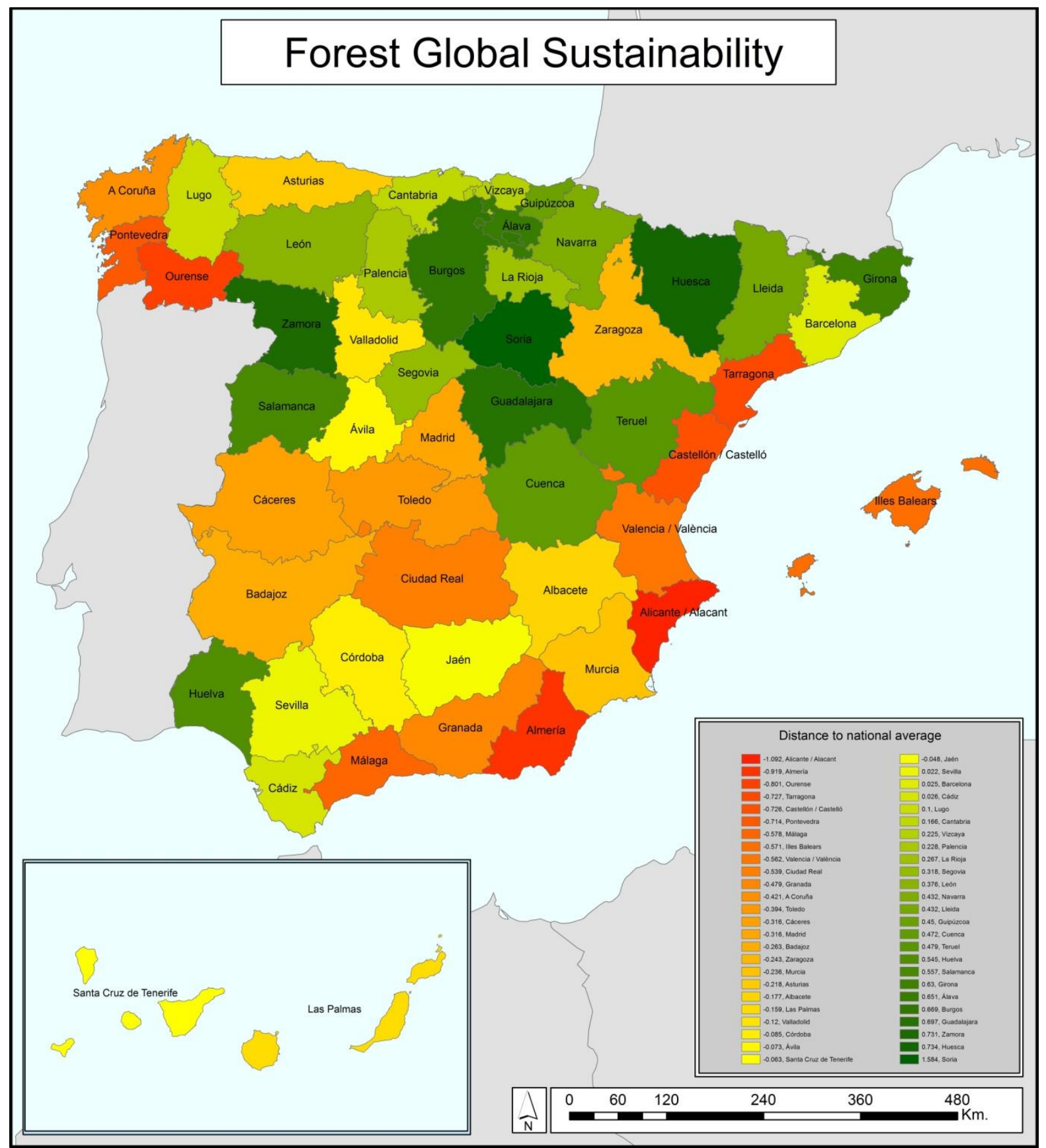

Fig. 2 .Forest global sustainability.

provinces of Galicia and the centre-north of Spain plus Huelva, the provinces that contain the most sustainable forestry. As mentioned above, the general conservation situation of the Spanish forest is not optimum. Results indicate a certain spatial gradient. Forest areas of the Mediterranean provinces are threatened by competition from other land uses more profitable. Economic growth in these provinces is based on other non-forest activities. The forests of the southern provinces of Galicia are continually threatened by wildfires. In contrast, the most sustainable provinces (central and northern Spain) build much of their local economies on traditional uses of mountains

Regarding the inter-relation of the sector indicators included in the global forestry index (FOR_GSI), there can be said to be relatively little correlation between them. The Pearson correlation 
index is close to 0 in most cases (Table 3 ). The FOR_ECOSI and FOR_SSI indices are inversely correlated. The dimension that is most closely correlated to the global sustainability index is the economic index (0.68) and the one that is least closely correlated is the social dimension $(0.16)$.

Hierarchical clustering of the three standard sectorial indices gave four groups of provinces at the level of four iterations (Table 4)

Map D (Appendix 5) shows the geographical distribution of the provinces that belong to each group. The provinces in group 1 have the worst values for environmental and economic sustainability and a low social sustainability. The provinces in group 2 reach the best levels for environmental sustainability, average values for social sustainability but have bad values for economic sustainability. Group 3 covers the provinces that have poor values for environmental and economic sustainability and moderate values for social sustainability. Finally, group 4 covers the Atlantic and Cantabrian provinces together with Zamora and Salamanca, which have the highest values for economic sustainability, medium-low values for environmental sustainability and the worst data for social sustainability
Figure 3 shows the 50 Spanish provinces in a cube, grouped by their clusters and the values of each of the indices for environmental, economic and social sustainability. This shows that no Spanish province is on the right, front and top part of the cube, which is where the most sustainable provinces in all dimensions would be located. Therefore, the analysis shows that, overall, despite their strategic importance Spanish forests still are quite far from values for minimum desirable sustainability levels

In general, the differences between both weighting methods applied are small in terms of results (Appendix 6). For instance, the unweighted global sustainability index of Spain reaches a value of -0.1561 versus -0.2677 if both the indicators and dimensions are weighted, and -0.2745 when only the dimensions are weighted. Taking into account the ranking of forest sustainability indicators using weights in indicators and dimensions or in dimensions, only $6 \%$ of Spanish provinces are in the same position as they do in the ranking without weights. Furthermore, taking into consideration the position with a margin of variation of $+/-5$ positions, coincidences rise to $60 \%$ of provinces.

Table 3

Pearson correlation indices between the sector indices and the global forest sustainability index

\begin{tabular}{l|r|r|r|r}
\hline & \multicolumn{1}{|c}{ FOR_ESI } & \multicolumn{1}{c}{ FOR_ECOSI } & \multicolumn{1}{c}{ FOR_SSI } & \multicolumn{1}{c}{ FOR_GSI } \\
\hline FOR_ESI & 1.0000 & 0.1750 & $0.3310^{*}$ & $0.6320^{* *}$ \\
\hline FOR_ECOSI & 0.1750 & 1.0000 & $-0.4450^{* *}$ & $0.6830^{* *}$ \\
\hline FOR_SSI & $0.3310^{*}$ & $-0.4450 * *$ & 1.0000 & 0.1600 \\
\hline FOR_GSI & $0.6320 * *$ & $0.6830 * *$ & 0.1600 & 1.0000 \\
\hline
\end{tabular}

* Correlation is significant at the 0.05 level (2-tailed)

** Correlation is significant at the 0.01 level (2-tailed)

Table 4

Average values for sector sustainability indices in each group of provinces ( $\mathrm{Z}$ values)

\begin{tabular}{lccccc}
\hline & \multicolumn{5}{c}{ Clúster } \\
\cline { 2 - 6 } & & \multicolumn{2}{c}{2} & 3 & 4 \\
\hline Z_FOR_ESI & -.5766 & 1.3245 & -.5534 & -.1342 \\
Z_FOR_ECOSI & -.3594 & $-.0546^{-}$ & -.6528 & 1.6607 \\
Z_FOR_SSI & & $-.4851^{-}$ & .5183 & .9278 & -1.2330 \\
\hline
\end{tabular}


The remaining $40 \%$ of the provinces experience major changes in the ranking. Two groups (Map E, Appendix 5) are identified. The first contains 11 provinces which improve exponentially their ranking positions if either weighted integration method is applied. Despite their moderate economic data, they have good environmental indicators. Teruel, Cuenca and Leon, for example, ascend 8 or 10 positions. The second group brings together nine provinces that worsen their positions in the ranking. Although they achieve the best economic results, their values on environmental indicators are rather moderate or bad. Vizcaya, Salamanca, Zamora and Las Palmas are cases that fall in the ranking till 14 positions. In other cases, good social outcomes are not sufficient to offset the moderate or bad environmental indicators (Huelva and Sevilla).

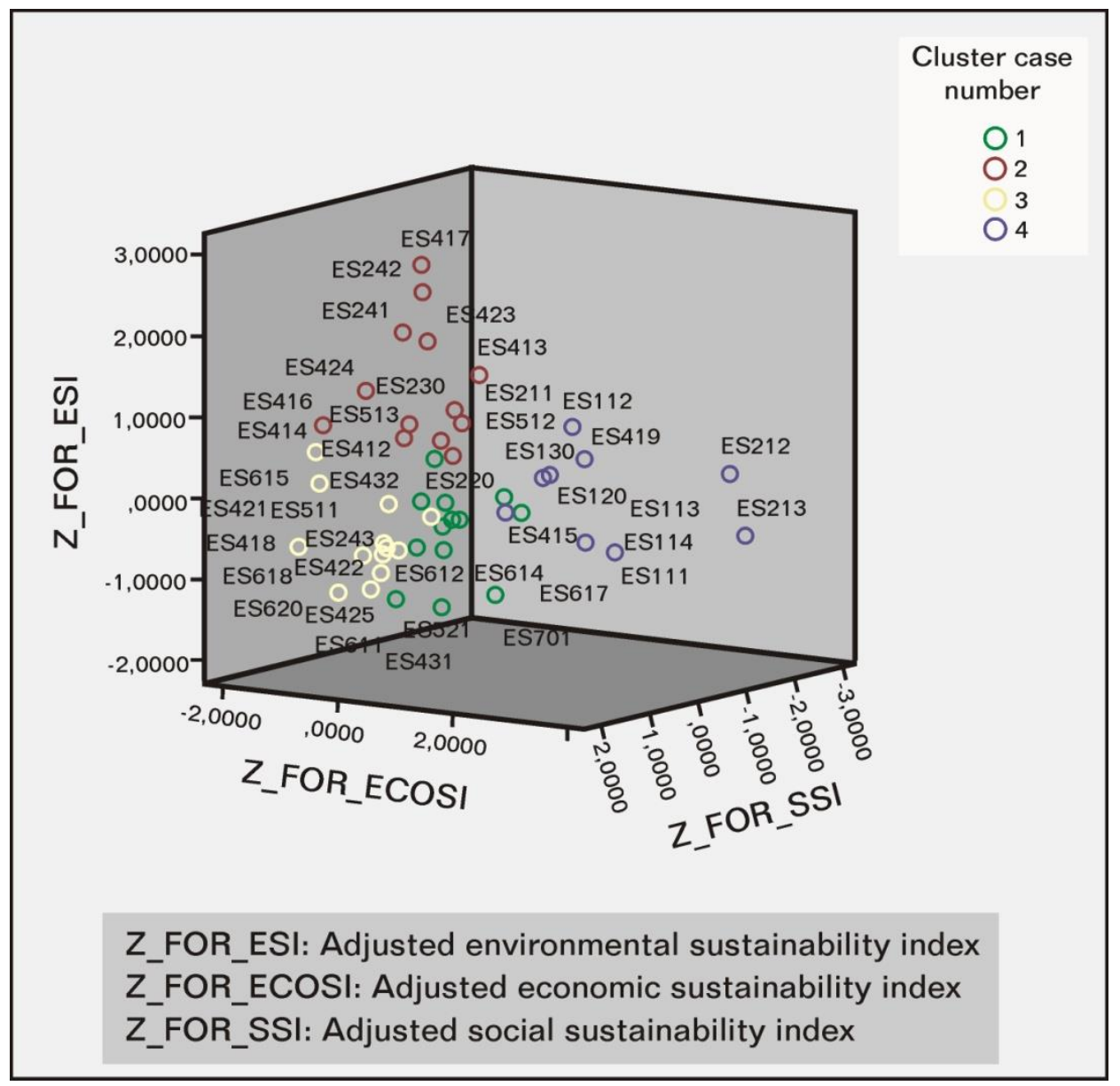

Fig. 3. Grouped representation of environmental, economic and social sustainability indices for Spanish forestry by province.

\section{Discussion}

Despite the persistence of a major scientific debate and the lack of agreement, from a methodological point of view this work has considered three dimensions of sustainability (Nijkamp, 1990; Gerdessen and Pascucci, 2013) in order to follow the conventional approach, and because its graphic representation is relatively simple and understandable by managers. Also, the relationship between the value of each indicator and a target value (Maes et al., 2011) and the standardisation of data facilitate the development of a ranking allowing to compare the results between provinces and to establish time trends. In addition, the weighting methods used could be considered close to the geographic reality taking into consideration the imbalance in the number of indicators of each sustainability dimension and their respective priority level.

There is also controversy about the desirability of using, for each indicator, a common TV for Spain 
or, alternatively, a dynamic and different TV adapted to the peculiarities of each province. A priori, this idea is suggestive. However, its implementation prevents the comparison of results by province and with the national average. In addition, not always objective values adapted to the specificities of each province can be found.

In any case, it is necessary to emphasise the desirability of transferring research results to end users and managers in order to facilitate the process of decision making (Mori and Christodoulou, 2012), and the design of policies tailored to the peculiarities of each territory. The present work has tried to involve the end-users to ensure the social utility of the results. However, this goal is not easy to achieve due to power decentralisation and sometimes the lack of coordination between forest planning and management, on the one hand, and sustainable development, on the other hand

\section{Conclusions}

Despite the relevance and topicality of sustainable forestry at regional level, very few studies have been conducted in this area in Spain and in Europe. The results show significant differences in forestry sustainability between different groups of provinces: the northern provinces of Spain versus provinces of south-eastern Spain. The methodology proposed provides a set of results (indicators, matrixes, maps and graphs) forming a useful diagnostic tool for facilitating decisions by the managers of forest ecosystems and the Protected Areas inside them. The proposed system of indicators also provides a point of reference and information that may be of use to policymakers when designing or adjusting socio-economic policies linked to forests and the protection of nature and of biodiversity. For instance, it facilitates the coordination of a national forestry policy in Spain. It could also orientate regional forest policies encouraging differentiated interventions in specific provinces owing to their singularities and the existence of territorial boundaries with administrative competence at that level.

Data standardisation makes it easier to compare different geographical areas. The methodology is explained in as much detail as possible so that it can be replicated (with necessary adaptations) in other studies, especially in the Mediterranean basin countries as well as in other geographic areas presenting similar forest characteristics.

There are, however, still a number of methodological caveats that need to be explored and resolved in future research. The controversy about the advantages and disadvantages of using a complex versus a simple or un-integrated set of indicators is still open. Similarly, the debate concerning the convenience to integrate indices with or without weights remains open. It would be important to accept the challenge of giving continuity to the approach presented here, for example by building a time series data. It would thus be possible to analyse forest sustainability in a dynamic way over time and adapt forestry policy and management according to the results achieved.

In connection with forest sustainability assessment, our aim also is to explore more in depth the role played by Protected Areas. In addition, further indicator validation and sensitivity analyses are to be carried out. A systematic stakeholder consultation process would be helpful to verify the extent to which the proposed indicators are meaningful and whether other relevant aspects must be included in the assessment.

\section{Acknowledgements}

This research has received funding from the European Union's Seventh Framework Programme under grant agreement KBBE-3-245233 "Sustainable Agri-Food Systems and Rural Development in the Mediterranean Partner Countries", and from the Spanish National R\&D project "DISESGLOB: Design of a Methodology for Monitoring and Assessing the Overall Sustainability of National Parks and the Influence of Expected Changes of Use" (CSO2013-42421-P). We would like to express our thanks for the support received from the Statistics Unit of the Centre for Human and Social Science (CSIC) in the statistical processing of the data. We also acknowledge the valuable comments from the Editor and two anonymous reviewers on an earlier version of this manuscript.

\section{Appendix A. Supplementary material}

Supplementary data associated with this article can be found, in the online version, at http://dx.doi.org/10.1016/j.geoforum.2015.12.013

\section{References}

Ang, F., Van Passel, S., 2010. The Sustainable Value approach: a clarifying and constructive comment. Ecological Economics 69, 2303-2306.

Arovuori, K., Horne, P., Kniivilä, M., Mili, S., Pyykkönen, P., Martínez-Vega, J. 2015. Sustainable agriculture and forestry in Southern Mediterranean countries: policy impacts and challenges. In: Petit, M., Montaigne, E., El Hadad-Gauthier, F., García, J.M., Mattas, K., 
Mili, S. (Eds.) Sustainable agricultural development. Springer, Heidelberg, pp. 255-288.

Bastianoni, S., Pulselli, F.M., Focardi, S., Tiezzi, E.B.P., Gramatica, P., 2008. Correlations and complementarities in data and methods through Principal Components Analysis (PCA) applied to the results of the SPIn-Eco Project. Journal of Environmental Management 86, 419-426.

Blanchet, D., 2012. La mesure du développement durable. Responsabilité et environnement. Problèmes économiques. 3044, 13-21.

Böhringer, C., Jochem, P.E.P., 2007. Measuring the inmeasurable. A survey of sustainability indices. Ecological Economics 63, 1-8.

Bossard, M., Feranec, J., Otahel, J., 2000. CORINE land cover technical guide-Addendum 2000. European Environment Agency. image2000.jrc.ec.europa.eu/reports/corine_tech_ guide_add.pdf

Butchart, S.H.M., Walpole, M., Collen, B. et al., 2010. Global biodiversity: Indicators of recent declines. Science 328 (5982), 1164-1168.

Chuvieco, E., Aguado, I., Jurdao, S., Pettinari, M.L., Yebra, M., Salas, J., Hantson, S., de la Riva, J., Ibarra, P., Rodrigues, M., Echeverría, M., Azqueta, D., Román, M.V., Bastarrika, A., Martínez, S., Recondo, C., Zapico, E., MartínezVega, J., 2012. Integrating geospatial information into firerisk assessment. International Journal of Wildland Fire 23 (5), 606-619.

Chuvieco, E., Martínez, S., Román, M.V., Hantson, S., Pettinari, L., 2013. Integration of ecological and socio-economic factors to assess global vulnerability to wildfire. Global Ecology and Biogeography 23 (2), 245-258.

Colombo, S.J., Chen, J., Ter-Mikaelian, M.T., McKechnie, J., Elkie, P.C., MacLean, H.L., Heath, L.S., 2012. Forest protection and forest harvest as strategies for ecological sustainability and climate change mitigation. Forest Ecology and Management 281, 140-151.

Costanza, R., d'Arge, R., de Groot, R., Farber, S., Grasso, M., Hannon, B., Limburg, K., Naeem, S., O’Neill, R.V., Paruelo, J., Raskin, R.G., Sutton, P., van den Belt, M., 1997. The value of the world's ecosystem services and natural capital. Nature 387, 253-260.

Cruickshank, M.M., Tomlinson, R.W., Trew, S., 2000. Application of CORINE land-cover mapping to estimate carbon stored in the vegetation of Ireland. Journal of Environmental Management 58, 269-287.

Dantsis, T., Douma, C., Giourga, C., Loumou, A., Polychronaki, E.A., 2010. A methodological approach to assess and compare the sustainability level of agricultural plant production systems. Ecological Indicators 10, 256-263.

Dantas de Paula, M., Groeneveld, J., Huth, A., 2015. Tropical forest degradation and recovery in fragmented landscapes. Simulating changes in tree community, forest hidrology and carbon balance. Global Ecology and Conservation 3, 664-677.

de Luis, M., Brunetti, M., González-Hidalgo, J.C., Longares, L.A., Martín-Vide, J., 2010. Changes in seasonal precipitation in the Iberian Peninsula during 1946-2005. Global Planet Change 74, 27-33.

Duguy, B., Alloza, J.A., Baeza, M.J., de la Riva, J., Echeverría, M., Ibarra, P., Llovet, J., Pérez Cabello, F., Rovira, P., Vallejo, R.V., 2012. Modelling the Ecological Vulnerability to Forest Fires in Mediterranean Ecosystems using Geographic Information Technologies. Environmental Management 50, 1012-1026.

Elbakidze, M., Angelstam, P., Sobolev, N., Degerman, E., Andersson, K., Axelsson, R., OlleHöjer, O., Wennberg, S., 2013. Protected Area as an Indicator of Ecological Sustainability? A Century of Development in Europe's Boreal Forest. Ambio 42, 201-214.

European Commission, 2006. Communication to the Council and the European Parliament.Development of agri-environmental indicators for monitoring the integration of environmental concerns into the common agricultural policy. COM (2006) 508 final. European Commission, Brussels.

European Commission, 2013. A new EU Forest Strategy: for forests and the forest-based sector. European Commission, Brussels. http://eurlex.europa.eu/legalcontent/EN/TXT/PDF/?uri=CELEX:52013DC06 59

EUROSTAT, 1999. Towards environmental pressure indicators for EU. Office for the Official Publications of the European Communities, Luxembourg.

FAO, 2002. The Pan-European Forest Process on Criteria and Indicators for Sustainable Forest Management, FAO, Rome, http://www.fao.org/docrep/004/ac135e/ac135e09 .htm\#TopOfPage.

FAO, 2014. State of the world's forests: Enhancing the socioeconomic benefits from forests. FAO, Rome, http://www.fao.org/3/a-i3710e/index.html

Fonseca, W., Rey Benayas, J.M., Alice, F.E. 2011. Carbon accumulation in the biomass and soil of different aged secondary forests in the humid tropics of Costa Rica. Forest Ecology and Management 262 (8), 1400-1408. 
FOREST EUROPE-UNECE-FAO, 2011. State of Europe's Forests 2011. Status and trends in sustainable forest management in Europe.

FRA, 2010. Global Forest Resources Assessment 2010. FAO, Rome. http://www.fao.org/docrep/013/i1757e/i1757e.pd $\mathrm{f}$

Fraser, E.D.G., Dougill, A.J., Mabee, W.E., Reed, M., McAlpine, P., 2006. Bottom up and top down: analysis of participatory processes for sustainability indicator identification as a pathway to community empowerment and sustainable environmental management. Journal of Environmental Management 78, 114-127.

García-Ruiz, J.M., López-Moreno, J.I., VicenteSerrano, S.M., Lasanta-Martínez, T., Beguería, S., 2011. Mediterranean water resources in a global change scenario. Earth-Science Reviews 105, 121-139.

Gerdessen, J.C., Pascucci, S., 2013. Data Envelopment Analysis of sustainability indicators of European agricultural systems at regional level. Agricultural Systems 118, 78-90.

Grainger, A., 2012. Forest sustainability indicator systems as procedural policy tools in global environmental governance. Global Environmental Change 22, 147-160.

Hara, K., Uwasu, M., Yabar, H., Zhang, H., 2009. Sustainability assessment with time-series scores: a case study of Chinese provinces. Sustainability Science 4 (1), 81-97.

ITTO, 2003. ATO/ITTO Principles, Criteria and Indicators for the Sustainable Management of African Natural Forests. African Timber Organization/International Tropical Timber Organization, Yokohama.

Lasanta, T., Vicente-Serrano, S.M., 2012. Complex land cover change processes in semiarid Mediterranean regions: An approach using Landsat images in northeast Spain. Remote Sensing of Environment 124, 1-14.

Lei, C., Lin, Z., Zhang, Q., 2014. The spreading front of invasive species in favorable habitat or unfavorable habitat. Journal of Differential Equations 257, 145-166.

Lund, H.G., 1999. A "forest" by any other name ... Environmental Science \& Policy 2, 125-133.

Lund, H.G., 2002. When is a forest not a forest? Journal of Forestry 100 (8), 21-28.

Maes, W.H., Fontaine, M., Rongé, K., Hermy, M., Muys, B., 2011. A quantitative indicator framework for stand level evaluation and monitoring of environmentally sustainable forest management. Ecological Indicators 11, 468-479.

Martínez-Fernández, J., Ruiz-Benito, P., Zavala, M.A., 2015. Recent land cover changes in Spain across biogeographical regions and protection levels: Implications for conservation policies. Land Use Policy 44, 62-75.

Martínez-Vega, J., Echavarría, P., González Cascón, V., Martínez Cruz, N. 2009. Propuesta metodológica para el análisis de la sostenibilidad en la provincia de Cuenca. Boletín de la Asociación de Geógrafos Españoles 49, 281-308.

Martínez-Vega, J., Echavarría, P., Ibarra, P., Echeverría, M., Rodrigues, M. 2012. Valoración del paisaje de España peninsular en el contexto de la generación de un índice sintético de riesgo de incendios forestales. In: Martínez-Vega, J., Martín, M.P. (Eds.) Tecnologías de la Información Geográfica en el contexto del Cambio Global. CSIC-AGE, Madrid, pp. 133142.

Martínez-Vega, J., Echavarría, P., 2013. Propuesta inicial de una red ampliada de Áreas Protegidas en España peninsular bajo el enfoque de su conexión con la matriz territorial. Investigaciones Geográficas 60, 53-68.

Mather, A.S., 2001. Forests of consumption: postproductivism, postmaterialism and the postindustrial forest. Environment and Planning C 19, 249-268.

MCPFE, 1998. Pan-European criteria and indicators for sustainable forest management. In: Annex 1 of Resolution L2, Third Ministerial Conference on the Protection of Forests in Europe, 2-4 June 1998, Lisbon, Portugal. MCPFE Liaison Unit, Vienna.

Molin, P.G., 2010. Estimation of vegetation carbon stock in Portugal using land use/land cover data. University of Nova Lisboa, Lisboa.

Mori, K., Christodoulou, A., 2012. Review of sustainability indices and indicators: Towards a new City Sustainability Index (CSI). Environmental Impact Assessment Review 32, 94-106.

Morse, S., Fraser, E.D.G., 2005. Making "dirty" nations look clean? The nation state and the problem of selecting and weighting indices as tools for measuring progress towards sustainability. Geoforum 36, 625-640.

Myers, N., Mittermeier, R.A., Mittermeier, C.G., da Fonseca, G.A.B., Kent, J., 2000. Biodiversity hotspots for conservation priorities. Nature 403, 853-858.

Nijkamp, P., 1990. Regional Sustainable Development and Natural Resource Use. World Bank Annual Conference on Development Economics, Washington DC.

OECD, 1998. Environmental indicators: towards sustainable development. OECD, Paris.

Ojea, E., Ruiz-Benito, P., Markandya, A., Zavala, M.A., 2012. Wood provisioning in Mediterranean forests: A bottom-up spatial 
valuation approach. Forest Policy and Economics $20,78-88$.

OSE, 2011. Biodiversidad en España. Base de la sostenibilidad ante el cambio global. Observatorio de la Sostenibilidad en España, Madrid.

Pan T.C., Kao, J.., 2009. Inter-generational equity index for assessing environmental sustainability: an example on global warming. Ecological Indicators 9, 725-731.

Pintus, F., Giraud, J.P., 2009. Measuring agricultural and rural development. In: Hervieu, B., Thibault, H.L., (Eds.) Mediterra 2009: Rethinking rural development in the Mediterranean. CIHEAM and Blue Plan. Presses de Sciences Po, Paris, pp. 333-351.

Pülzl, H., Prokofieva, I., Berg, S., Rametsteiner, E., Aggestam, F., Wolfslehner, B., 2012. Indicator development in sustainability impact assessment: balancing theory and practice. European Journal of Forest Research 131, 35-46.

Rametsteiner, E., Pülzl, H., Alkan-Olsson, J., Frederiksen, P., 2011. Sustainability indicator development-science or political negotiation? Ecological Indicators 11, 61-70.

Rivas-Martínez, S., Cantó, P., Fernández-González, F., Pizarro, J., Sánchez-Mata, D., 1990. Biogeografía de la Península Ibérica, Islas Baleares y Canarias. Universidad Complutense, Madrid.

Rodrigues, G.S., Rodrigues, I.A., Buschinelli, C.C.A., de Barros, I., 2010. Integrated farm sustainability assessment for the environmental management of rural activities. Environmental Impact Assessment Review 30, 229-239.

Rodrigues, M., Ibarra, P., Echeverría, M., PérezCabello, F., de la Riva, J., 2014. A method for regional-scale assessment of vegetation recovery time after high-severity wildfires: Case study of Spain. Progress in Physical Geography 38 (5), 556-575.
Román, M.V., Azqueta, D., Rodrigues, M., 2013. Methodological approach to assess the socioeconomic vulnerability to wildfires in Spain. Forest Ecology and Management 294, 158-165.

Ruiz-Benito, P., Gómez-Aparicio, L., Paquette, A., Messier, C., Kattge, J., Zavala, M.A., 2014. Diversity increases carbon storage and tree productivity in Spanish forests. Global Ecology and Biogeography 23, 311-322.

Spangenberg, J., 1998. Sustainability indicators. A compass on the road towards sustainability. Wuppertal Institute, Wuppertal.

Stellmes, M., Röder, A., Udelhoven, T., Hill, J., 2013. Mapping syndromes of land change in Spain with remote sensing time series, demographic and climatic data. Land Use Policy 30, 685-702.

Van Calker, K.J., Berentsen, P.B.M., de Boer, I.M.J., Giesen, G.W.J., Huirne, R.B.M., 2007. Modelling worker physical health and societal sustainability at farm level: an application to conventional and organic dairy farming. Agricultural Systems 94, 205-219.

Van Calker, K.J., Berentsen, P.B.M., Giesen, G.W.J., Huirne, R.B.M., 2008. Maximising sustainability of Dutch dairy farming systems for different stakeholders: a modelling approach. Ecological Economics 65, 407-419.

Van Dijk, M.P., Zhang, M., 2005. Sustainability indices as a tool for urban managers, evidence from four medium-sized Chinese cities. Environmental Impact Assessment Review 25, 667-688.

Van Passel, S., Nevens, F., Mathijs, E., Van Huylenbroeck, G., 2007. Measuring farm sustainability and explaining differences in sustainable efficiency. Ecological Economics 62, 149-161.

WCED, 1987. Our Common Future. Oxford Paperbacks, United Nations. 


\section{Appendix 1}

Final selection of indicators of forest sustainability.

Character: $\mathrm{P}=$ Priority, $\mathrm{C}=$ Complementary; Indicator Type: $\mathrm{S}=$ State, $\mathrm{P}=$ Pressure, $\mathrm{R}=$ Response.






\begin{tabular}{|c|c|c|c|c|c|c|c|c|c|c|c|}
\hline & Forest conservation & C & $\begin{array}{l}\text { FOR_P }{ }_{1} F \\
\text { FOR_P } P_{2} F\end{array}$ & \begin{tabular}{|l} 
Protected \\
Forests \\
\\
\\
Protective \\
Forests
\end{tabular} & $\begin{array}{l}\text { Proportion of } \\
\text { surface } \\
\text { protected } \\
\text { forests with } \\
\text { respect to the } \\
\text { total area } \\
\\
\text { Proportion of } \\
\text { surface } \\
\text { protective } \\
\text { forests } \\
\text { (including soil, } \\
\text { water and } \\
\text { other } \\
\text { ecosystem } \\
\text { functions, } \\
\text { infrastructure) } \\
\text { with respect } \\
\text { to the total } \\
\text { area }\end{array}$ & $\begin{array}{l}(\mathrm{SPedF} / \mathrm{TA})^{*} 100 \\
(\mathrm{SPveF} / \mathrm{TA})^{*} 100\end{array}$ & $\%$ & 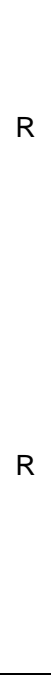 & $\begin{array}{c}\text { FOREST } \\
\text { EUROPE- } \\
\text { UNECE-FAO, } \\
2011 \\
\\
\\
\\
\\
\text { FOREST } \\
\text { EUROPE- } \\
\text { UNECE-FAO, } \\
2011\end{array}$ & $\begin{array}{l}\text { increase } \\
\text { increase }\end{array}$ & $\begin{array}{l}\text { CORINE } \\
\text { Land Cover } \\
2006 \text { and } \\
\text { map of } \\
\text { Protected } \\
\text { Areas } \\
\text { (Europarc- } \\
\text { Spain) } \\
\\
\\
\\
\text { National } \\
\text { Forest } \\
\text { Inventory } \\
\text { IFN-3 }\end{array}$ \\
\hline Landscape & Diversity & $\mathrm{P}$ & LAND_SDI & \begin{tabular}{|l} 
Simpson \\
Diversity \\
Index
\end{tabular} & $\begin{array}{l}\text { Indicator that } \\
\text { measures the } \\
\text { forest } \\
\text { landscape } \\
\text { diversity }\end{array}$ & McGarigal, 2013 & $\begin{array}{l}\text { Scale from } \\
0 \text { (worst) to } \\
100 \text { (best) }\end{array}$ & $\mathrm{s}$ & $\begin{array}{c}\text { EC, 2006; } \\
\text { Rodrigues et } \\
\text { al., 2010; } \\
\text { FOREST } \\
\text { EUROPE- } \\
\text { UNECE-FAO, } \\
2011 ;\end{array}$ & increase & $\begin{array}{l}\text { Forest map } \\
\text { of Spain } \\
\text { 1:50,000 / } \\
\text { FIREGLOBE } \\
\text { project }\end{array}$ \\
\hline $\begin{array}{c}\text { Biodiversit } \\
y\end{array}$ & Protected areas & $\mathrm{P}$ & BIO_TPA & $\begin{array}{l}\text { Percentage of } \\
\text { Terrestrial } \\
\text { Protected } \\
\text { Areas }\end{array}$ & \begin{tabular}{|l} 
Percentage of \\
Terrestrial \\
Protected \\
Areas inside \\
forest area \\
over the Total \\
Surface (\%) \\
with respect \\
to the \\
Extended \\
Network of \\
Protected \\
Areas inside \\
forest area \\
proposed by \\
author, 2013.
\end{tabular} & $(\mathrm{TPAF} / \mathrm{ENPAF})^{\star} 100$ & $\%$ & $\mathrm{R}$ & $\begin{array}{l} \\
\\
\text { EC, 2006; } \\
\text { Pintus \& } \\
\text { Giraud, 2009; } \\
\text { Butchart et al., } \\
2010 ; \\
\text { Elbakidze et al., } \\
2013\end{array}$ & increase & $\begin{array}{c}\text { Database of } \\
\text { Biodiversity } \\
\text { (Ministry of } \\
\text { Environment) } \\
\text {, GIS of } \\
\text { Europarc- } \\
\text { Spain; GIS } \\
\text { data; } \\
\text { Martínez- } \\
\text { Vega and } \\
\text { Echavarría, } \\
2013\end{array}$ \\
\hline
\end{tabular}




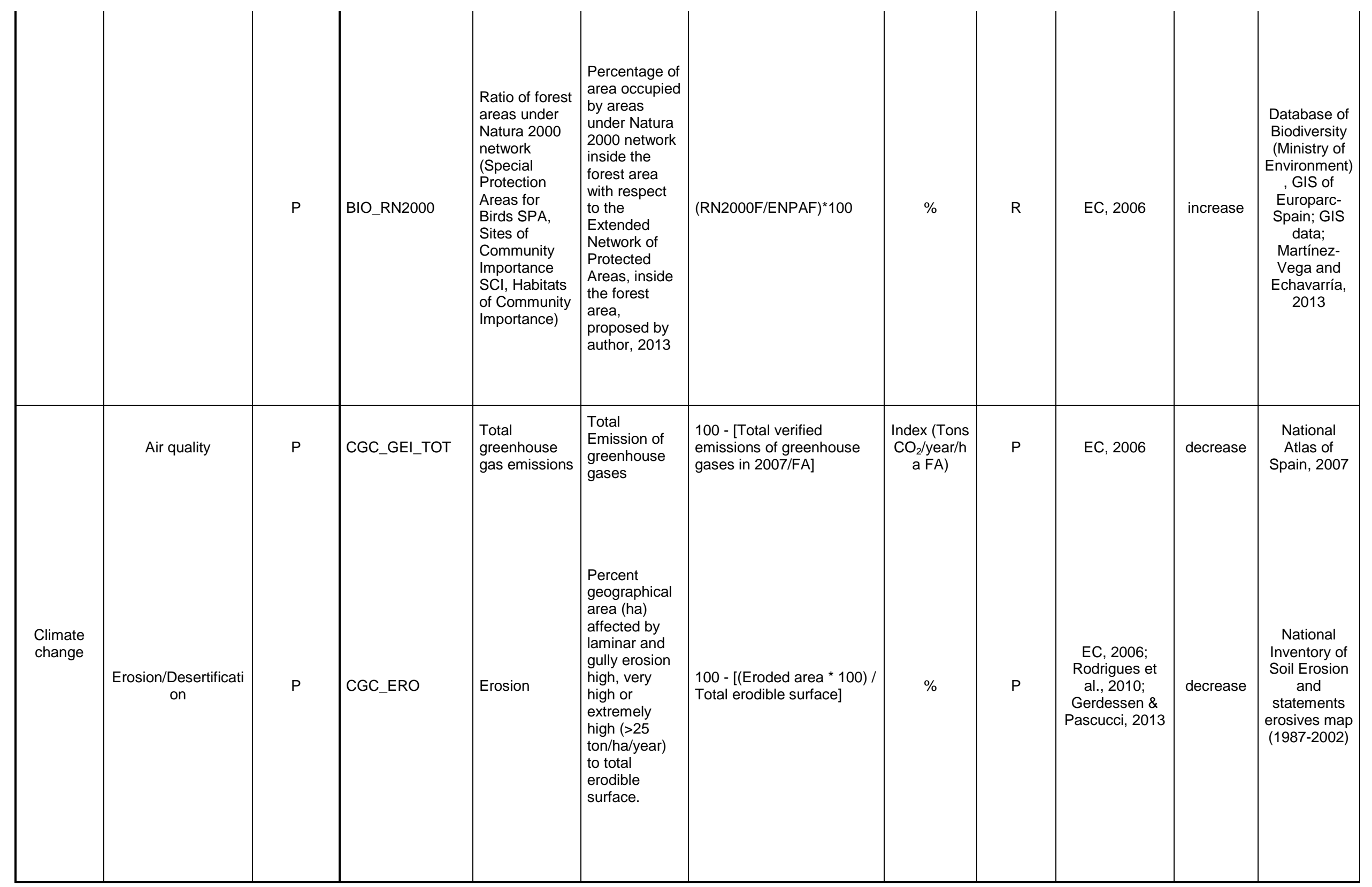




\begin{tabular}{|c|c|c|c|c|c|c|c|c|c|c|c|c|}
\hline 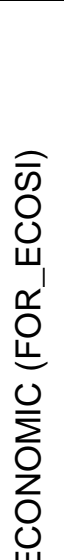 & Forestry & Economic function & $\mathrm{P}$ & $\begin{array}{l}\text { FOR_ESPF } \\
\text { FOR_ESRF } \\
\text { FOR_ESES }\end{array}$ & $\begin{array}{l}\text { Expenditures } \\
\text { for services } \\
\text { (Productive } \\
\text { function) } \\
\\
\text { Expenditures } \\
\text { for services } \\
\text { (Recreational } \\
\text { function) } \\
\text { Expenditures } \\
\text { for services } \\
\text { (environment } \\
\text { al services) }\end{array}$ & $\begin{array}{l}\text { Total } \\
\text { revenues } \\
\text { from services } \\
\text { (Productive } \\
\text { function: } \\
\text { wood, cork, } \\
\text { pine, etc.) } \\
\text { Total } \\
\text { revenues } \\
\text { from services } \\
\text { (Recreational } \\
\text { function) } \\
\text { Total } \\
\text { revenues } \\
\text { from services } \\
\text { (environment } \\
\text { al services) } \\
\end{array}$ & $\begin{array}{l}\text { Revenues from services } \\
\text { (Productive function) / } \mathrm{km}^{2} \\
\text { FA } \\
\\
\text { Revenues from services } \\
\text { (Recreational function) / } \\
\mathrm{km}^{2} \mathrm{FA} \\
\\
\text { Revenues from services } \\
\text { (environmental services) / } \\
\mathrm{km}^{2} \mathrm{FA}\end{array}$ & $\begin{array}{l}\text { Thousands } \\
€ / \mathrm{km}^{2} \mathrm{FA}\end{array}$ & $\mathrm{S}$ & $\begin{array}{c}\text { FOREST } \\
\text { EUROPE- } \\
\text { UNECE-FAO. } \\
2011 ; \text { Ojea et } \\
\text { al., } 2012 \\
\\
\text { FOREST } \\
\text { EUROPE- } \\
\text { UNECE-FAO. } \\
2011 \\
\text { FOREST } \\
\text { EUROPE- } \\
\text { UNECE-FAO. } \\
2011\end{array}$ & $\begin{array}{l}\text { increase } \\
\text { increase } \\
\text { increase }\end{array}$ & $\begin{array}{l}\text { National } \\
\text { Forest } \\
\text { Inventory } \\
\text { IFN-3/ } \\
\text { CORINE- } \\
\text { Land Cover } \\
2006\end{array}$ \\
\hline & $\begin{array}{l}\text { Rural } \\
\text { developme } \\
\text { nt }\end{array}$ & Horizontal axis & $\mathrm{P}$ & HA_GDP & $\begin{array}{l}\text { Growth of } \\
\text { GDP per } \\
\text { capita }\end{array}$ & $\begin{array}{l}\text { Evolution of } \\
\text { the GDP per } \\
\text { capita }\end{array}$ & (GDP2008*100)/GDP2000 & $\begin{array}{c}\text { index base } \\
100\end{array}$ & $\mathrm{~S}$ & $\begin{array}{l}\text { van Dijk \& } \\
\text { Zhang, 2005; } \\
\text { EC, } 2006\end{array}$ & increase & $\begin{array}{l}\text { INE (National } \\
\text { Statistical } \\
\text { Institute) }\end{array}$ \\
\hline 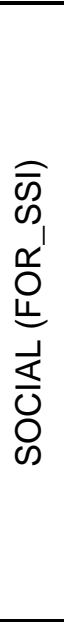 & $\begin{array}{c}\text { Rural } \\
\text { developme } \\
\text { nt }\end{array}$ & $\begin{array}{l}\text { Rural diversity } \\
\text { Rural poverty } \\
\text { Employment }\end{array}$ & $\mathrm{C}$ & $\begin{array}{l}\text { AGR_NFE } \\
\text { AGR_SF } \\
\text { AGR_ASE }\end{array}$ & $\begin{array}{l}\begin{array}{l}\text { Non-farming } \\
\text { enterprises }\end{array} \\
\text { Small farms } \\
\text { Agricultural } \\
\text { hired } \\
\text { employment }\end{array}$ & $\begin{array}{l}\text { Percentage of } \\
\text { non-farming } \\
\text { enterprises in } \\
\text { rural areas } \\
\text { Percentage of } \\
\text { farms with an } \\
\text { acreage of } \\
\text { less than } 10 \\
\text { ha } \\
\text { Share of } \\
\text { agricultural } \\
\text { hired } \\
\text { employment }\end{array}$ & $\begin{array}{l}\text { percentage of non- } \\
\text { agricultural businesses to } \\
\text { total businesses }\end{array}$ & $\%$ & $\mathrm{~S}$ & $\begin{array}{c}\text { Pintus \& } \\
\text { Giraud, 2009 } \\
\text { Pintus \& } \\
\text { Giraud, 2009 }\end{array}$ & decrease & $\begin{array}{c}\text { Agricultural } \\
\text { Censuses of } \\
1999 \text { and } \\
2009 \text { and } \\
\text { Central } \\
\text { Business } \\
\text { Directories of } \\
1999 \text { and } \\
2009 \\
\text { Agricultural } \\
\text { Census } 2009 \\
\text { Agricultural } \\
\text { Census } 2009\end{array}$ \\
\hline
\end{tabular}






Clarification of the target values for each indicator:

FOR_FA: According to the Spanish Forest Plan (2002-2032) 3,800,000 ha are expected to be reforested by the end of the plan period. Therefore, the forest area will grow to $29,816,981$ ha, which represents $58.87 \%$ o hectares of forest area and the improvement of forest management. This amount represents an average carbon storage of 16.02 tha of forest area.
FOR AR: According to Annex 1 of the publication State Europe's Forest, the average annual change in forest area of all forests of SW Europe is $0.9 \%$. As in this indicator it has been calculated the rate of change in

forest area between 2000 and 2006 (CLC), we set the target value by $5.4 \%(0.90 * 6$ years).
FOR_FA_tree: The Spanish Forestry Plan (2002-2032) establishes the objective to attain, by $2030,65 \%$ of wooded forest area per total forest area.

FOR_FA- tree cap: According to the Spanish Forestry Plan (2002-2032), is set as the objective to be achieved in 2032 0.45 he hab wooded forest are.

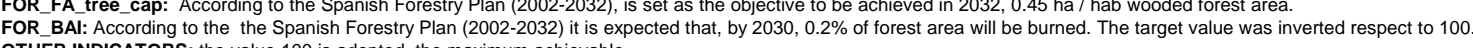

OTHER INDICATORS: the value 100 is adopted, the maximum achievable 


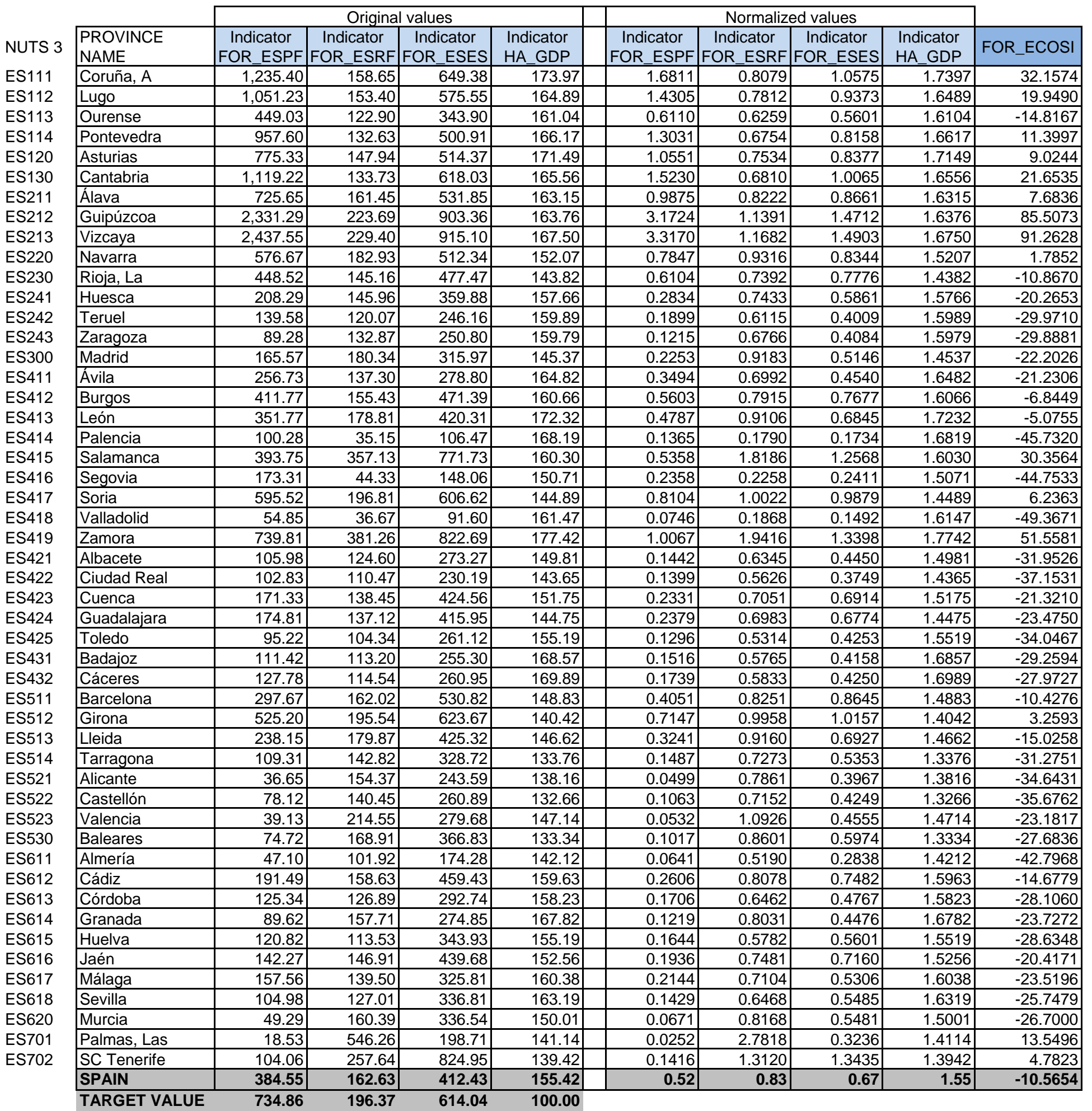

Clarification of the target values for each indicator:

FOR_ESPF: According to the frequency distribution histogram, the 85th percentile is elected as desirable minimum value FOR_ESRF: According to the frequency distribution histogram, the 85th percentile is elected as desirable minimum value FOR_ESES: According to the frequency distribution histogram, the 85th percentile is elected as desirable minimum value HA_GDP: The aim is to maintain at least the per capita income level. 
Appendix 4. Social sustainability indicators: original and normalizated values

\begin{tabular}{|c|c|c|c|c|c|c|c|c|}
\hline \multirow[b]{2}{*}{ NUTS 3} & & \multicolumn{3}{|c|}{ Oriainal values } & \multicolumn{3}{|c|}{ Normalized values } & \multirow[b]{2}{*}{ FOR_SSI } \\
\hline & $\begin{array}{l}\text { PROVINCE } \\
\text { NAME }\end{array}$ & $\begin{array}{c}\text { Indicator } \\
\text { AGR NFE }\end{array}$ & $\begin{array}{l}\text { Indicator } \\
\text { AGR_SF }\end{array}$ & $\begin{array}{c}\text { Indicator } \\
\text { AGR_ASE }\end{array}$ & $\begin{array}{c}\text { Indicator } \\
\text { AGR_NFE }\end{array}$ & $\begin{array}{l}\text { Indicator } \\
\text { AGR_SF }\end{array}$ & $\begin{array}{c}\text { Indicator } \\
\text { AGR_ASE }\end{array}$ & \\
\hline ES111 & Coruña, A & 74.66 & 18.40 & 4.15 & 0.9334 & 0.3335 & 0.1000 & -54.4351 \\
\hline ES112 & Lugo & 49.41 & 36.95 & 4.25 & 0.8141 & 0.6695 & 0.1023 & -47.1348 \\
\hline ES113 & Ourense & 64.03 & 16.96 & 5.50 & 0.9603 & 0.3074 & 0.1325 & -53.3293 \\
\hline ES114 & Pontevedra & 83.00 & 13.84 & 6.11 & 0.8500 & 0.2508 & 0.1473 & -58.3976 \\
\hline ES120 & \begin{tabular}{|l} 
Asturias \\
\end{tabular} & 75.03 & 29.84 & 5.11 & 0.9297 & 0.5407 & 0.1231 & -46.8859 \\
\hline ES130 & Cantabria & 79.28 & 44.54 & 10.67 & 0.8872 & 0.8071 & 0.2571 & -34.9523 \\
\hline ES211 & Álava & 85.63 & 54.30 & 31.43 & 0.8237 & 0.9840 & 0.7572 & -14.5007 \\
\hline ES212 & Guipúzcoa & 91.45 & 18.76 & 5.04 & 0.7655 & 0.3400 & 0.1214 & -59.1028 \\
\hline ES213 & Vizcaya & 92.58 & 14.49 & 6.49 & 0.7542 & 0.2625 & 0.1564 & -60.8942 \\
\hline ES220 & Navarra & 73.17 & 50.36 & 28.33 & 0.9483 & 0.9127 & 0.6827 & -15.2103 \\
\hline ES230 & Rioja, La & 69.69 & 34.63 & 26.54 & 0.9831 & 0.6275 & 0.6396 & -24.9901 \\
\hline ES241 & Huesca & 50.84 & 62.76 & 27.50 & 0.8284 & 1.1373 & 0.6626 & -12.3905 \\
\hline ES242 & Teruel & 44.64 & 57.75 & 16.14 & 0.7664 & 1.0465 & 0.3888 & -26.6060 \\
\hline ES243 & Zaragoza & 73.06 & 51.20 & 31.47 & 0.9494 & 0.9278 & 0.7584 & -12.1474 \\
\hline ES300 & Madrid & 98.41 & 42.01 & 40.09 & 0.6959 & 0.7613 & 0.9660 & -19.2278 \\
\hline ES411 & Ávila & 50.25 & 50.85 & 16.85 & 0.8225 & 0.9216 & 0.4060 & -28.3290 \\
\hline ES412 & Burgos & 66.94 & 72.92 & 22.21 & 0.9894 & 1.3214 & 0.5351 & -5.1354 \\
\hline ES413 & León & 68.87 & 51.44 & 7.35 & 0.9913 & 0.9322 & 0.1770 & -29.9846 \\
\hline ES414 & Palencia & 60.70 & 80.72 & 27.44 & 0.9270 & 1.4629 & 0.6612 & 1.7014 \\
\hline ES415 & Salamanca & 62.87 & 66.00 & 17.25 & 0.9487 & 1.1962 & 0.4156 & -14.6500 \\
\hline ES416 & Segovia & 56.89 & 70.88 & 34.40 & 0.8889 & 1.2846 & 0.8290 & 0.0850 \\
\hline ES417 & Soria & 53.74 & 81.06 & 27.63 & 0.8574 & 1.4691 & 0.6657 & -0.2608 \\
\hline ES418 & Valladolid & 77.45 & 72.56 & 39.31 & 0.9055 & 1.3150 & 0.9473 & 5.5899 \\
\hline ES419 & Zamora & 47.37 & 61.75 & 9.14 & 0.7937 & 1.1191 & 0.2203 & -28.8964 \\
\hline ES421 & Albacete & 56.72 & 40.78 & 37.77 & 0.8872 & 0.7391 & 0.9102 & -15.4494 \\
\hline ES422 & Ciudad Real & 45.92 & 41.43 & 40.81 & 0.7792 & 0.7509 & 0.9833 & -16.2234 \\
\hline ES423 & Cuenca & 40.27 & 51.56 & 27.88 & 0.7227 & 0.9345 & 0.6717 & -22.3689 \\
\hline ES424 & Guadalajara & 67.12 & 62.87 & 35.01 & 0.9912 & 1.1394 & 0.8437 & -0.8557 \\
\hline ES425 & Toledo & 57.01 & 38.33 & 38.46 & 0.8901 & 0.6946 & 0.9267 & -16.2843 \\
\hline ES431 & Badajoz & 52.19 & 43.06 & 42.79 & 0.8419 & 0.7803 & 1.0310 & -11.5574 \\
\hline ES432 & Cáceres & 48.63 & 34.54 & 34.11 & 0.8063 & 0.6260 & 0.8219 & -24.8588 \\
\hline ES511 & Barcelona & 97.90 & 43.24 & 43.24 & 0.7010 & 0.7837 & 1.0420 & -15.7763 \\
\hline ES512 & Girona & 90.22 & 52.77 & 40.57 & 0.7778 & 0.9563 & 0.9775 & -9.6129 \\
\hline ES513 & Lleida & 64.57 & 54.54 & 32.00 & 0.9657 & 0.9884 & 0.7712 & -9.1609 \\
\hline ES514 & Tarragona & 70.15 & 21.11 & 19.68 & 0.9785 & 0.3826 & 0.4741 & -38.8251 \\
\hline ES521 & \begin{tabular}{|l|} 
Alicante \\
\end{tabular} & 83.99 & 10.84 & 34.87 & 0.8401 & 0.1964 & 0.8402 & -37.4436 \\
\hline ES522 & Castellón & 61.67 & 11.71 & 27.55 & 0.9367 & 0.2123 & 0.6637 & -39.5736 \\
\hline ES523 & \begin{tabular}{|l} 
Valencia \\
\end{tabular} & 73.06 & 8.39 & 34.16 & 0.9494 & 0.1521 & 0.8232 & -35.8405 \\
\hline ES530 & Baleares & 89.52 & 31.01 & 25.03 & 0.7848 & 0.5619 & 0.6032 & -35.0036 \\
\hline ES611 & Almería & 65.47 & 14.11 & 41.18 & 0.9747 & 0.2557 & 0.9923 & -25.9117 \\
\hline ES612 & Cádiz & 85.78 & 39.99 & 52.23 & 0.8222 & 0.7247 & 1.2586 & -6.4838 \\
\hline ES613 & Córdoba & 56.98 & 32.54 & 58.95 & 0.8898 & 0.5896 & 1.4206 & -3.3321 \\
\hline ES614 & Granada & 59.02 & 22.59 & 32.04 & 0.9102 & 0.4094 & 0.7721 & -30.2745 \\
\hline ES615 & Huelva & 68.12 & 31.62 & 75.60 & 0.9988 & 0.5730 & 1.8217 & 13.1170 \\
\hline ES616 & Jaén & 35.66 & 18.02 & 52.19 & 0.6766 & 0.3266 & 1.2575 & -24.6435 \\
\hline ES617 & Málaga & 80.99 & 18.12 & 37.03 & 0.8701 & 0.3283 & 0.8922 & -30.3102 \\
\hline ES618 & Sevilla & 80.28 & 42.99 & 65.40 & 0.8772 & 0.7791 & 1.5759 & 7.7397 \\
\hline ES620 & \begin{tabular}{|l|} 
Murcia \\
\end{tabular} & 74.52 & 21.91 & 63.08 & 0.9348 & 0.3970 & 1.5200 & -4.9399 \\
\hline ES701 & Palmas, Las & 93.31 & 8.71 & 58.37 & 0.7469 & 0.1578 & 1.4065 & -22.9633 \\
\hline \multirow[t]{3}{*}{ ES702 } & SC Tenerife & 88.14 & 4.06 & 47.80 & 0.7986 & 0.0737 & 1.1518 & -32.5304 \\
\hline & SPAIN & 77.18 & 33.33 & 32.27 & 0.9082 & 0.6039 & 0.7775 & -23.6795 \\
\hline & TARGET VAL & 68.00 & 55.18 & 41.50 & & & & \\
\hline
\end{tabular}

Clarification of the target values for each indicator:

AGR_NFE: In the absence of an objective value in the legislation and in the literature we have taken as desirable minimum value the median value of the data series, which in this case is 68.00 .

AGR_SF: According to the frequency distribution histogram, the 80th percentile is elected as desirable minimum value

AGR_ASE: According to the frequency distribution histogram, the 80th percentile is elected as desirable minimum value 
Appendix 5. Maps of the various dimensions of forest sustainability and cluster of provinces according to their forest sustainability.

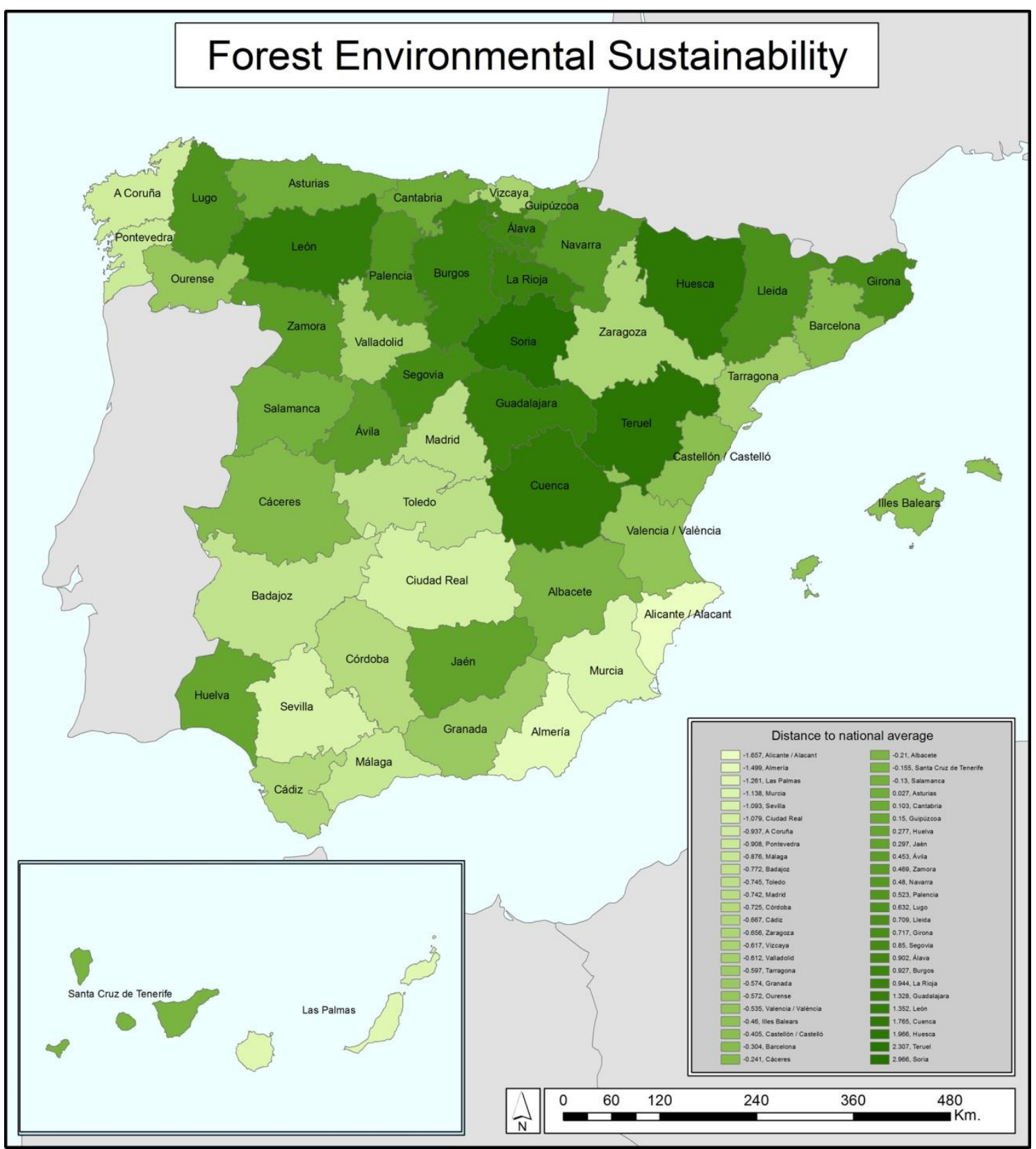

Map A. Forest Environmental Sustainability 


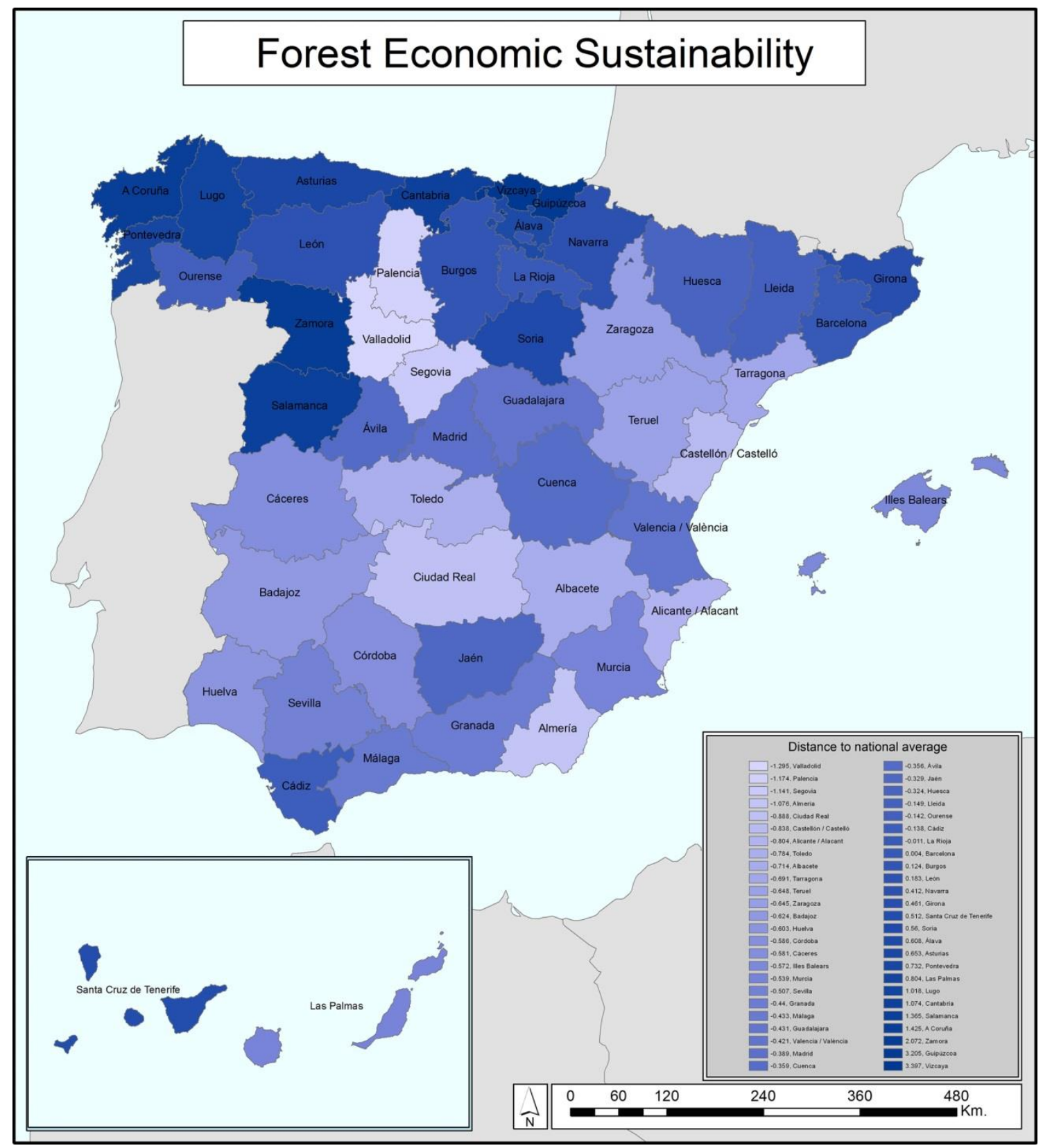

Map B. Forest Economic Sustainability 


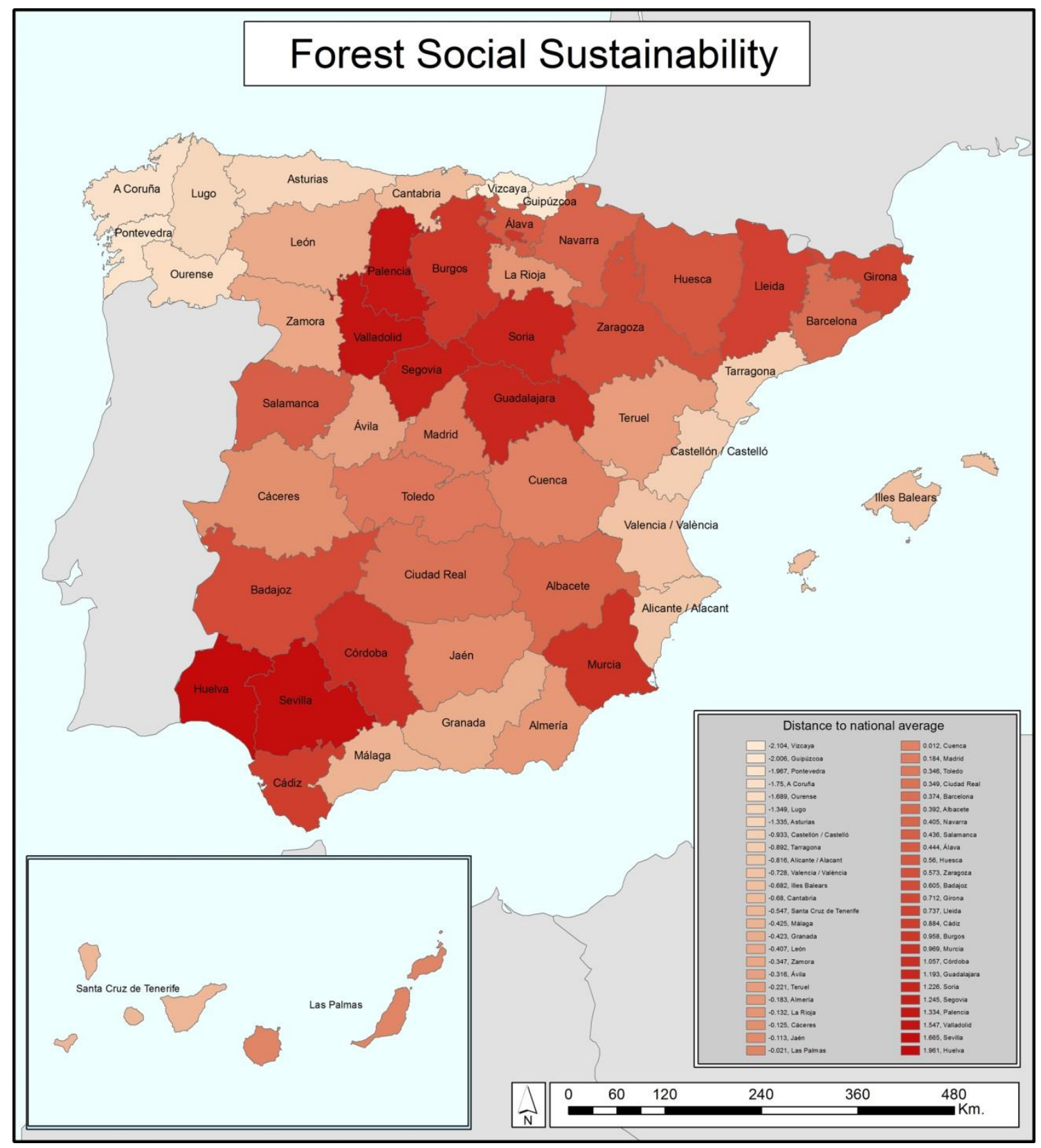

Map C. Forest Social Sustainability 


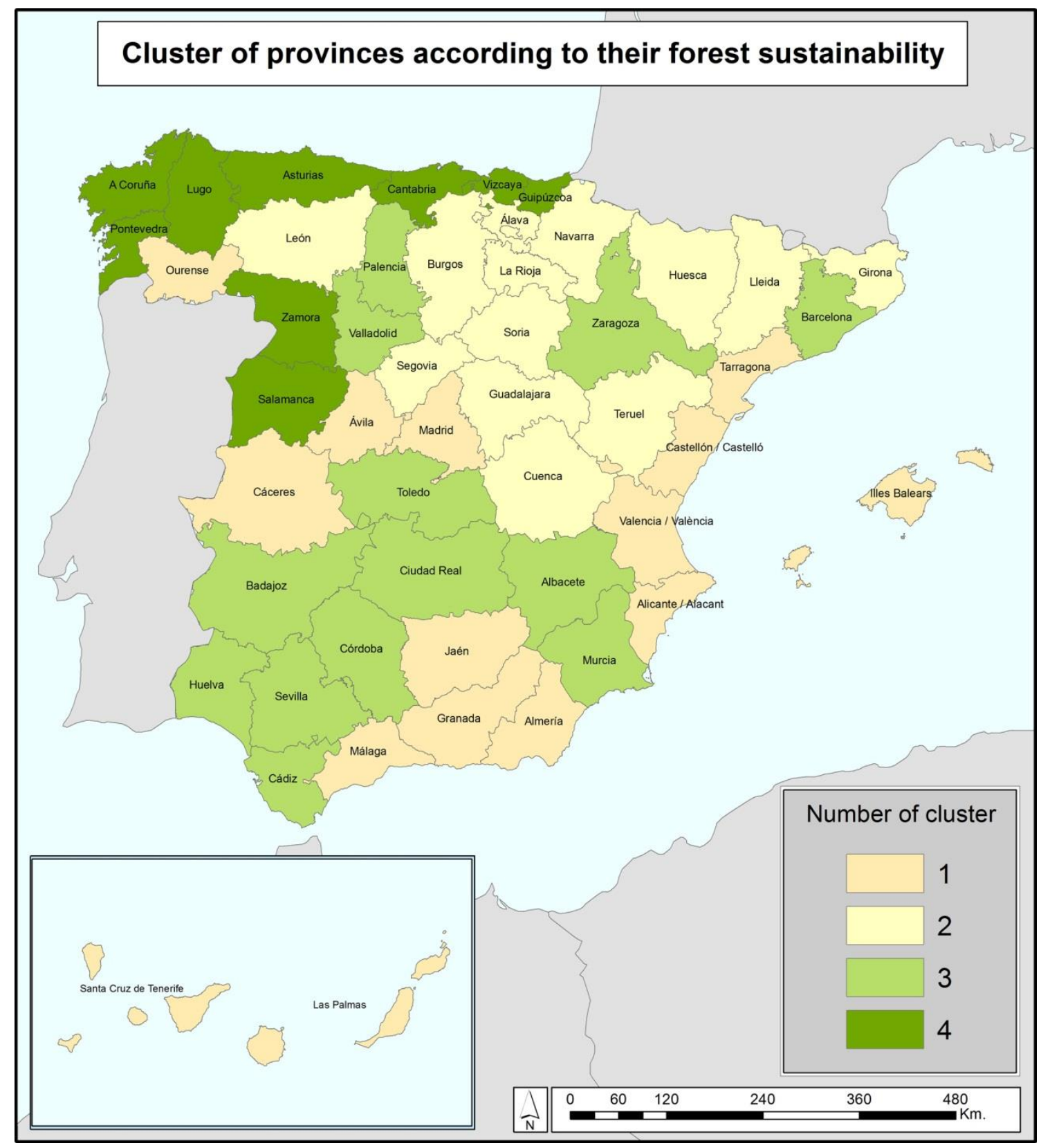

Map D. Cluster of provinces according to their forest sustainability. 


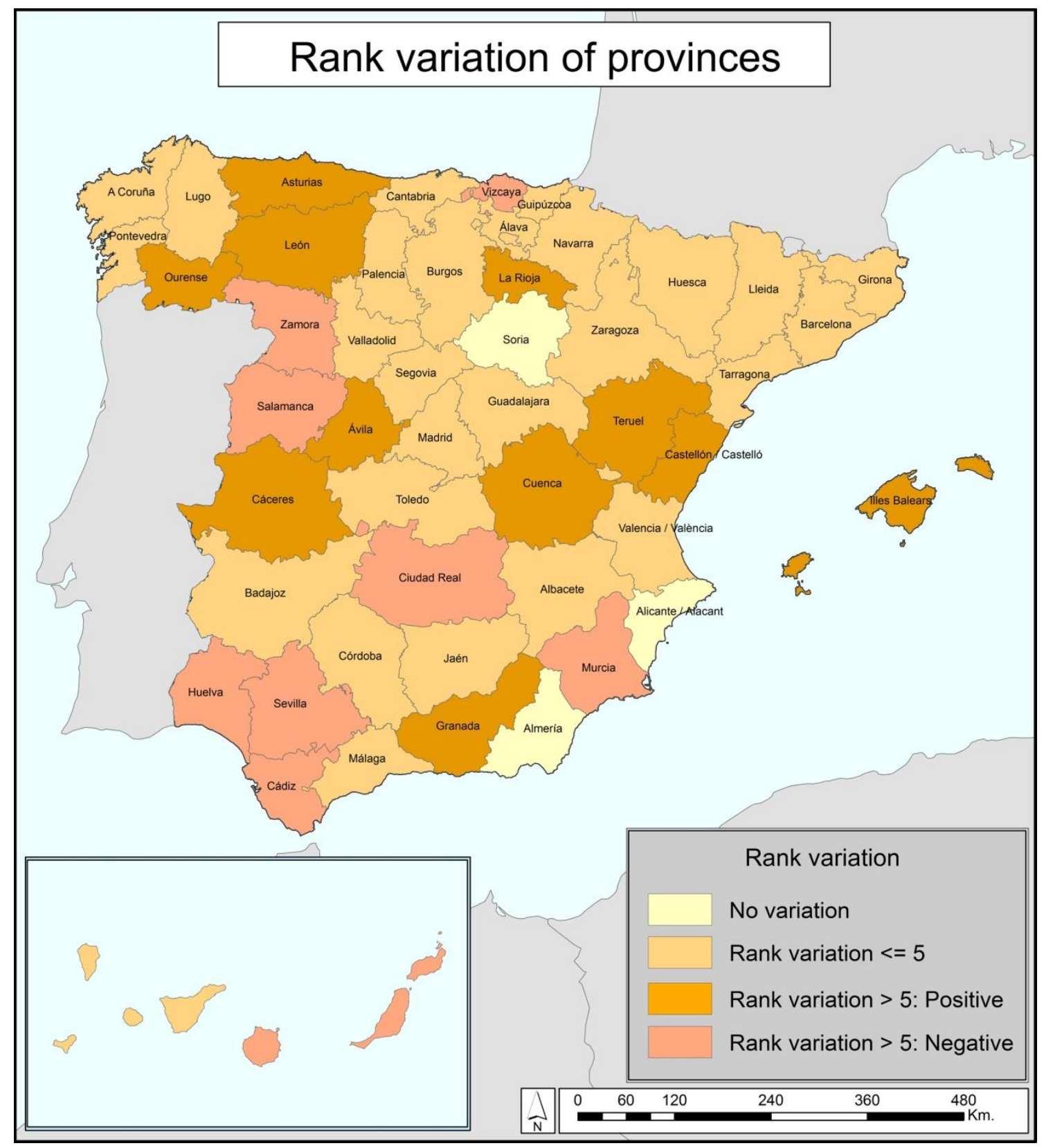

Map E. Unweighted vs weighted global sustainability index: rank variation of provinces. 


\section{Appendix 6. Comparison between unweighted and weighted global sustainability index}

\begin{tabular}{|c|c|c|c|c|}
\hline NUTS 3 & PROVINCE NAME & Z_FOR_GSI_UW & Z_FOR_GSI_WD & Z_FOR_GSI_WDI \\
\hline ES111 & Coruña, A & -0.4201 & -0.5861 & -0.6167 \\
\hline ES112 & Lugo & 0.1008 & 0.4125 & 0.4355 \\
\hline ES113 & Ourense & -0.8004 & -0.6528 & -0.6426 \\
\hline ES114 & Pontevedra & -0.7138 & -0.7384 & -0.7419 \\
\hline ES120 & Asturias & -0.2180 & -0.0519 & -0.0363 \\
\hline ES130 & Cantabria & 0.1663 & 0.1801 & 0.1913 \\
\hline ES211 & Alava & 0.6517 & 0.7747 & 0.8134 \\
\hline ES212 & Guipúzcoa & 0.4502 & 0.4383 & 0.4857 \\
\hline ES213 & Vizcaya & 0.2258 & -0.0366 & -0.0499 \\
\hline ES220 & Navarra & 0.4328 & 0.4558 & 0.4645 \\
\hline ES230 & Rioja, La & 0.2676 & 0.5922 & 0.6243 \\
\hline ES241 & Huesca & 0.7344 & 1.2977 & 1.2900 \\
\hline ES242 & Teruel & 0.4799 & 1.3376 & 1.2886 \\
\hline ES243 & Zaragoza & -0.2422 & -0.4689 & -0.4877 \\
\hline ES300 & Madrid & -0.3151 & -0.5320 & -0.5212 \\
\hline ES411 & Avila & -0.0724 & 0.1766 & 0.2065 \\
\hline ES412 & Burgos & 0.6700 & 0.7713 & 0.7893 \\
\hline ES413 & León & 0.3763 & 0.8545 & 0.8816 \\
\hline ES414 & Palencia & 0.2281 & 0.3056 & 0.3020 \\
\hline ES415 & Salamanca & 0.5572 & 0.2540 & 0.3035 \\
\hline ES416 & Segovia & 0.3184 & 0.5116 & 0.5222 \\
\hline ES417 & Soria & 1.5846 & 2.2246 & 2.1858 \\
\hline ES418 & Valladolid & -0.1196 & -0.4245 & -0.4338 \\
\hline ES419 & Zamora & 0.7320 & 0.6679 & 0.6766 \\
\hline ES421 & Albacete & -0.1769 & -0.2199 & -0.2301 \\
\hline ES422 & Ciudad Real & -0.5385 & -0.8258 & -0.8505 \\
\hline ES423 & Cuenca & 0.4728 & 1.0773 & 1.0620 \\
\hline ES424 & Guadalajara & 0.6970 & 0.9562 & 0.9712 \\
\hline ES425 & Toledo & -0.3939 & -0.5887 & -0.5998 \\
\hline ES431 & Badajoz & -0.2630 & -0.5351 & -0.5092 \\
\hline ES432 & Cáceres & -0.3152 & -0.2910 & -0.2747 \\
\hline ES511 & Barcelona & 0.0251 & -0.1403 & -0.1214 \\
\hline ES512 & Girona & 0.6305 & 0.6655 & 0.7257 \\
\hline ES513 & Lleida & 0.4327 & 0.5420 & 0.5585 \\
\hline ES514 & Tarragona & -0.7264 & -0.6596 & -0.6850 \\
\hline ES521 & Alicante & -1.0920 & -1.3599 & -1.4368 \\
\hline ES522 & Castellón & -0.7250 & -0.5703 & -0.5495 \\
\hline ES523 & Valencia & -0.5612 & -0.5411 & -0.5462 \\
\hline ES530 & Baleares & -0.5710 & -0.5155 & -0.5207 \\
\hline ES611 & Almería & -0.9189 & -1.2167 & -1.2886 \\
\hline ES612 & Cádiz & 0.0268 & -0.3282 & -0.3437 \\
\hline ES613 & Córdoba & -0.0842 & -0.4296 & -0.4311 \\
\hline ES614 & Granada & -0.4783 & -0.5240 & -0.5355 \\
\hline ES615 & Huelva & 0.5453 & 0.3541 & 0.3626 \\
\hline ES616 & Jaén & -0.0479 & 0.1110 & 0.1048 \\
\hline ES617 & Málaga & -0.5774 & -0.7194 & -0.7538 \\
\hline ES618 & Sevilla & 0.0222 & -0.5617 & -0.5860 \\
\hline ES620 & Murcia & -0.2354 & -0.7015 & -0.7675 \\
\hline ES701 & Palmas, Las & -0.1587 & -0.6613 & -0.6573 \\
\hline \multirow[t]{2}{*}{ ES702 } & Santa Cruz de Tenerife & -0.0629 & -0.0801 & -0.0282 \\
\hline & SPAIN & -0.1561 & -0.2745 & -0.2677 \\
\hline
\end{tabular}

Z_FOR_GSI_UW = Forest Global Sustainability Index in units Z:

simple average of the Z_FOR_ESI, Z_FOR_ECOSI and Z_FOR_SSI indicators,

Z_FOR_GSI_WD = Forest Global Sustainability Index in units Z:

weighted average applying a different weight to each of the 3 intermediate indexes

(Dimensions), proportional to the number of indicators used for calculation: $w_{-} E S I=1.95$;

w_ECOSI $=0.6 ; \mathrm{w} \_S S I=0.45$

Z_FOR_GSI_WDI = Forest Global Sustainability Index in units Z:

weighted average applying a different weight to each of the indicators

( $\mathrm{P}=$ priority $/ \mathrm{C}=$ complementary) and the 3 intermediate indexes (Dimensions), proportional to the number of indicators used for calculation: $w_{-} P=1.2 ; w_{-} C=1.0 ; w_{-} E S I=1.95$;

w_ECOSI $=0.6 ; \mathrm{w} \_S S I=0.45$ 